National Water-Quality Assessment Program Toxic Substances Hydrology Program

\title{
Environmental Settings of Streams Sampled for Mercury in New York and South Carolina, 2005-09
}

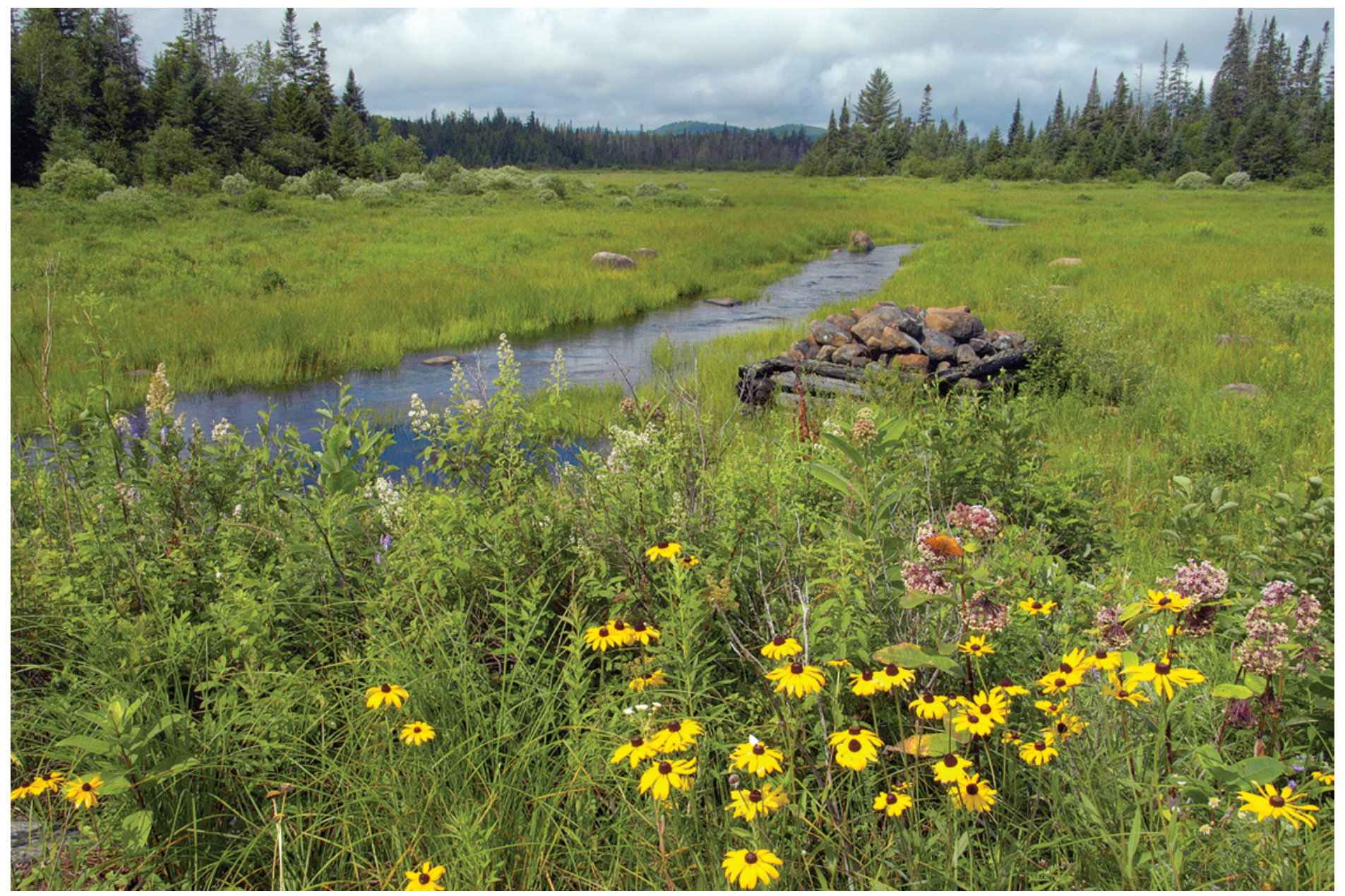

Open-File Report 2011-1318

U.S. Department of the Interior U.S. Geological Survey 
Cover: Sixmile Brook near Long Lake, New York, photograph by Dennis A. Wentz, U.S. Geological Survey. 


\section{Environmental Settings of Streams Sampled for Mercury in New York and South Carolina, 2005-09}

By Barbara C. Scudder Eikenberry, Karen Riva-Murray, Martyn J. Smith, Paul M. Bradley, Daniel T. Button, Jimmy M. Clark, Douglas A. Burns, and Celeste A. Journey

National Water-Quality Assessment Program

Toxic Substances Hydrology Program

Open-File Report 2011-1318 


\title{
U.S. Department of the Interior \\ KEN SALAZAR, Secretary \\ U.S. Geological Survey \\ Marcia K. McNutt, Director
}

\author{
U.S. Geological Survey, Reston, Virginia: 2012
}

For more information on the USGS - the Federal source for science about the Earth, its natural and living resources, natural hazards, and the environment, visit http://www.usgs.gov or call 1-888-ASK-USGS.

For an overview of USGS information products, including maps, imagery, and publications, visit http://www.usgs.gov/pubprod

To order this and other USGS information products, visit http://store.usgs.gov

Any use of trade, product, or firm names is for descriptive purposes only and does not imply endorsement by the U.S. Government.

Although this report is in the public domain, permission must be secured from the individual copyright owners to reproduce any copyrighted materials contained within this report.

Suggested citation:

Scudder Eikenberry, B.C., Riva-Murray, Karen, Smith, M.J., Bradley, P.M., Button, D.T., Clark, J.M., Burns, D.A., and Journey, C.A., 2012, Environmental settings of selected streams sampled for mercury in New York and South Carolina, 2005-09: U.S. Geological Survey Open-File Report 2011-1318, 36 p. 


\section{Foreword}

The U.S. Geological Survey (USGS) is committed to providing the Nation with reliable scientific information that helps to enhance and protect the overall quality of life and that facilitates effective management of water, biological, energy, and mineral resources (http://www.usgs. gov//). Information on the Nation's water resources is critical to ensuring long-term availability of water that is safe for drinking and recreation and is suitable for industry, irrigation, and fish and wildlife. Population growth and increasing demands for water make the availability of that water, measured in terms of quantity and quality, even more essential to the long-term sustainability of our communities and ecosystems.

The USGS implemented the National Water-Quality Assessment (NAWQA) Program in 1991 to support national, regional, State, and local information needs and decisions related to water-quality management and policy (http://water.usgs.gov/nawqa). The NAWOA Program is designed to answer: What is the quality of our Nation's streams and groundwater? How are conditions changing over time? How do natural features and human activities affect the quality of streams and groundwater, and where are those effects most pronounced? By combining information on water chemistry, physical characteristics, stream habitat, and aquatic life, the NAWQA Program aims to provide science-based insights for current and emerging water issues and priorities. From 1991 to 2001, the NAWQA Program completed interdisciplinary assessments and established a baseline understanding of water-quality conditions in 51 of the Nation's river basins and aquifers, referred to as Study Units (http://water.usgs.gov/nawqa/studies/ study_units.html).

National and regional assessments are ongoing in the second decade (2001-2012) of the NAWQA Program as 42 of the 51 Study Units are selectively reassessed. These assessments extend the findings in the Study Units by determining water-quality status and trends at sites that have been consistently monitored for more than a decade, and filling critical gaps in characterizing the quality of surface water and groundwater. For example, increased emphasis has been placed on assessing the quality of source water and finished water associated with many of the Nation's largest community water systems. During the second decade, NAWQA is addressing five national priority topics that build an understanding of how natural features and human activities affect water quality, and establish links between sources of contaminants, the transport of those contaminants through the hydrologic system, and the potential effects of contaminants on humans and aquatic ecosystems. Included are studies on the fate of agricultural chemicals, effects of urbanization on stream ecosystems, bioaccumulation of mercury in stream ecosystems, effects of nutrient enrichment on aquatic ecosystems, and transport of contaminants to public-supply wells. In addition, national syntheses of information on pesticides, volatile organic compounds (VOCs), nutrients, trace elements, and aquatic ecology are continuing.

The USGS aims to disseminate credible, timely, and relevant science information to address practical and effective water-resource management and strategies that protect and restore water quality. We hope this NAWQA publication will provide you with insights and information to meet your needs, and will foster increased citizen awareness and involvement in the protection and restoration of our Nation's waters. 
The USGS recognizes that a national assessment by a single program cannot address all waterresource issues of interest. External coordination at all levels is critical for cost-effective management, regulation, and conservation of our Nation's water resources. The NAWQA Program, therefore, depends on advice and information from other agencies-Federal, State, regional, interstate, Tribal, and local—as well as nongovernmental organizations, industry, academia, and other stakeholder groups. Your assistance and suggestions are greatly appreciated.

William H. Werkheiser USGS Associate Director for Water

\section{Acknowledgments}

The authors wish to thank many USGS personnel who contributed their guidance, especially Terri L. Arnold (Illinois Water Science Center) and Todd D. Stuntebeck (Wisconsin Water Science Center) who provided comments on an earlier version of the manuscript. Access was graciously provided to the Fishing Brook study area by The Nature Conservancy, Finch Pruyn \& Company, and RMK Timberland, and to the McTier Creek study area by the family of Senator Strom Thurmond. The authors also thank the staff of the Adirondack Ecological Center (State University of New York-College of Environmental Science and Forestry) for field laboratory space used in sample processing. 


\section{Contents}

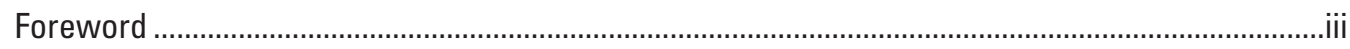

Acknowledgments .............................................................................................................

Conversion Factors, Datums, and Abbreviations and Acronyms ..................................................vii

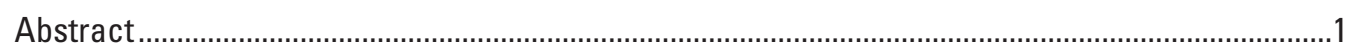

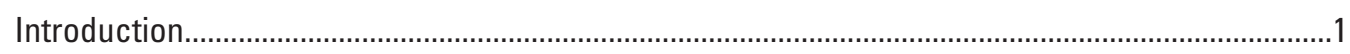

Environmental Setting and Mercury Cycling ……...................................................................

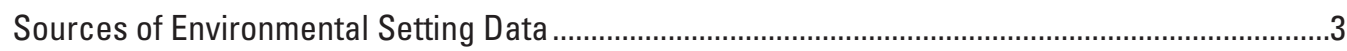

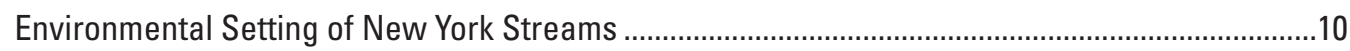

Upper Hudson River Basin ................................................................................................

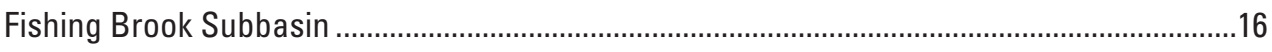

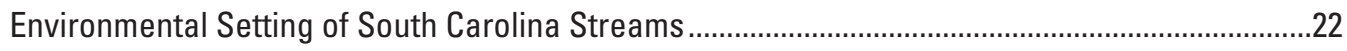

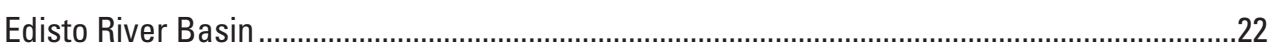

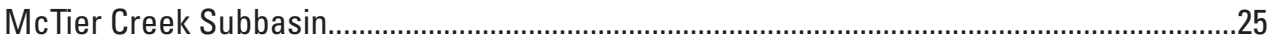

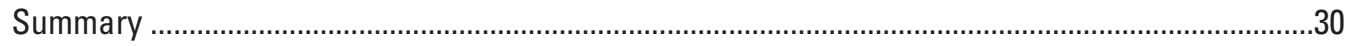

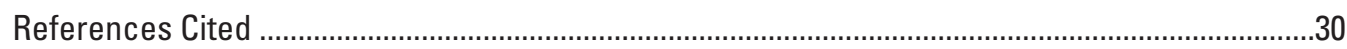

\section{Figures}

1. Map showing locations of New York and South Carolina study basins.............................2

2. Photograph of Hudson River near Newcomb, New York (Site 27 in table 1 and figure 3) (summer)....................................................................................................

3. Map showing land use/land cover of Upper Hudson River Basin near Newcomb, New York, with nested outline of Fishing Brook Subbasin in headwaters ......................15

4. Photograph of Fishing Brook above County Line Flow near Long Lake, New York (Site 10 in table 1 and figure 3) (summer) ....................................................................16

5. Photograph of Fishing Brook (County Line Flow outlet) near Newcomb, New York (Site 12 in table 1 and figure 3) (summer).

6A. Map showing detailed land use/land cover and wetland cover for Fishing Brook Subbasin, New York: land use/land cover, based on National Land Cover Dataset for 2001 (NLCD01)

6B. Map showing detailed land use/land cover and wetland cover for Fishing Brook Subbasin, New York: wetland cover, based on New York State Adirondack Park Agency data

7. Satellite image of Fishing Brook Subbasin, New York, showing sampling locations

8. Photographs of $(A)$ Sixmile Brook near Long Lake, New York (Site 7) (summer), major tributary to Fishing Brook and (B) Pickwacket Pond Inlet near Long Lake, N.Y. (Site 9) (summer).

9. Photograph of Edisto River Basin near Givhans, South Carolina (Site 54 in table 1 and figure 10) (winter).

10. Map showing detailed land use/land cover for Edisto River Basin near Givhans, South Carolina, with nested outline of McTier Creek Subbasin 
11. Photograph of McTier Creek near Monetta, South Carolina (Site 30 in table 1 and figure 10) (summer)

12A. Maps showing detailed land use/land cover and wetland cover for McTier Creek Subbasin: land use/land cover, based on National Land Cover Dataset for 2001

12B. Maps showing detailed land use/land cover and wetland cover for McTier Creek Subbasin: wetland cover, based on U.S. Fish and Wildlife Service National Wetlands Inventory

13. Satellite image of McTier Creek Subbasin, South Carolina, showing sampling locations. Map numbers refer to sites listed in table 1.

14. Photograph of Gully Creek at Bridge on Shoals Road near Monetta, South Carolina, major tributary to McTier Creek (Site 31) (fall)

\section{Tables}

1. Map numbers and complete site names with basic basin characteristics for streams sampled in New York and South Carolina for U.S. Geological Survey mercury studies, 2005-09.

2. Sources of environmental-setting data for streams sampled in New York and South Carolina for U.S. Geological Survey mercury studies, 2005-09.

3. Selected locations in the National Atmospheric Deposition Program-Mercury Deposition Network (NADP-MDN) used to estimate atmospheric wet deposition of total mercury in the Hudson River Basin, New York, and the Edisto River Basin, South Carolina.....

4. Mean air temperature, precipitation, and atmospheric mercury data for primary stream basins sampled in New York and South Carolina for U.S. Geological Survey mercury studies, 2005-09

5. Land use/land cover data for streams sampled in New York and South Carolina for U.S. Geological Survey mercury studies, 2005-09

6. Hydrologic data for primary stream sites sampled in New York and South Carolina for U.S. Geological Survey mercury studies for period of record and study period of 2005-09

7. Mean annual water temperature and range for primary stream sites sampled in New York and South Carolina for U.S. Geological Survey mercury studies, 2005-09

\section{Appendixes}

Appendix 1. Detailed Geographic Information System data for selected streams sampled in New York for U.S Geological Survey mercury studies, 2005-09 Available online.

Appendix 2. Detailed Geographic Information System data for selected streams sampled in South Carolina for U.S. Geological Survey mercury studies, 2005-09 Available online. 


\section{Conversion Factors, Datums, and Abbreviations and Acronyms}

\begin{tabular}{lcl}
\hline \multicolumn{1}{c}{ Multiply } & By & \multicolumn{1}{c}{ To obtain } \\
\hline millimeter $(\mathrm{mm})$ & Length & inch (in.) \\
meter $(\mathrm{m})$ & 0.03937 & foot $(\mathrm{ft})$ \\
kilometer $(\mathrm{km})$ & 3.281 & mile $(\mathrm{mi})$ \\
\hline & 0.6214 & \\
\hline hectare $($ ha) & Area & square mile $\left(\mathrm{mi}^{2}\right)$ \\
square kilometer $\left(\mathrm{km}^{2}\right)$ & 0.003861 & square mile $\left(\mathrm{mi}^{2}\right)$ \\
\hline & 0.3861 & \\
\hline cubic meters per second $\left(\mathrm{m}^{3} / \mathrm{s}\right)$ & Flow rate & cubic feet per second $\left(\mathrm{ft}^{3} / \mathrm{s}\right)$ \\
\hline & 35.31 & ounce, avoirdupois $(\mathrm{oz})$ \\
\hline gram $(\mathrm{g})$ & Mass & \\
\hline
\end{tabular}

Temperature in degrees Celsius $\left({ }^{\circ} \mathrm{C}\right)$ may be converted to degrees Fahrenheit $\left({ }^{\circ} \mathrm{F}\right)$ as follows:

${ }^{\circ} \mathrm{F}=\left(1.8 x^{\circ} \mathrm{C}\right)+32$

Vertical coordinate information is referenced to the North American Vertical Datum of 1988 (NAVD 88).

Horizontal coordinate information is referenced to North American Datum of 1983 (NAD 83) unless otherwise noted.

Altitude, as used in this report, refers to distance above the vertical datum.

Latitude and longitude listed in table 1 and the appendixes are referenced to the North American Datum of 1927 (NAD 27).

Water year: The 12-month period, 0 ctober 1-September 30. The water year is designated by the calendar year in which it ends. 


\section{Abbreviations and Acronyms}

$\begin{array}{ll}\text { APA } & \text { New York State Adirondack Park Agency } \\ \text { CY } & \text { calendar year } \\ \text { ESRI } & \text { Environmental Systems Research Institute } \\ \text { GIS } & \text { geographic information system } \\ \text { Hg } & \text { mercury } \\ \text { KSAT } & \text { areal-weighted saturated hydraulic conductivity } \\ \text { MDN } & \text { Mercury Deposition Network of the National Atmospheric Deposition } \\ \text { MeHg } & \text { Program } \\ \text { NADP } & \text { methylmercury } \\ \text { NAIP } & \text { National Atmospheric Deposition Program } \\ \text { NAWOA } & \text { National Agriculture Imagery Program } \\ \text { NCDC } & \text { National Water-Quality Assessment Program } \\ \text { NLCD } & \text { National Climatic Data Center } \\ \text { NLCD01 } & \text { National Land Cover Dataset } \\ \text { NTN } & \text { National Land Cover Dataset for 2001 } \\ \text { NWI } & \text { National Trends Network of NADP } \\ \text { PRISM } & \text { U.S. Fish and Wildlife Service National Wetlands Inventory } \\ \text { SAGA } & \text { Parameter-elevation Regressions on Independent Slopes Model } \\ \text { SSURGO } & \text { System for Automated Geoscientific Analysis } \\ \text { USGS } & \text { U.S. Department of Agriculture Soil Survey Geographic database } \\ \text { WY } & \text { U.S. Geological Survey } \\ & \text { water year }\end{array}$




\title{
Environmental Settings of Streams Sampled for Mercury in New York and South Carolina, 2005-09
}

\author{
By Barbara C. Scudder Eikenberry, Karen Riva-Murray, Martyn J. Smith, Paul M. Bradley, Daniel T. Button, \\ Jimmy M. Clark, Douglas A. Burns, and Celeste A. Journey
}

\begin{abstract}
This report summarizes the environmental settings of streams in New York and South Carolina, where the U.S. Geological Survey completed detailed investigations during 2005-09 into factors contributing to mercury bioaccumulation in top-predator fish and other stream organisms. Descriptions of location, land use/land cover, climate, precipitation, atmospheric deposition, hydrology, water temperature, and other characteristics are provided. Atmospheric deposition is the dominant mercury source in the studied basins where biota, sediment, soil, and water were sampled for mercury and for physical and chemical characteristics believed to be important in mercury methylation and transport.
\end{abstract}

\section{Introduction}

In 2002, the U.S. Geological Survey (USGS) National Water-Quality Assessment (NAWQA) program began studies of mercury $(\mathrm{Hg})$ in stream and river ecosystems (henceforth referred to as 'streams') across the United States. These streams spanned a large range in $\mathrm{Hg}$ source strength and environmental settings. Initial studies focused on environmental factors contributing to bioavailability and bioaccumulation of $\mathrm{Hg}$ in stream ecosystems from single locations in each of eight study basins - two in Oregon, three in Wisconsin, and three in Florida (Bell and Lutz, 2008; Brigham and others, 2003, 2009; Chasar and others, 2009; Marvin-DiPasquale and others, 2009). Subsequent studies conducted during 2005-09 examined mercury cycling, transport, and bioaccumulation at multiple sites across two stream basins in New York and South Carolina. The purpose of this report is to describe the environmental settings of study basins in New York and South Carolina (fig. 1) and to serve as a reference document for other reports associated with the 2005-09 $\mathrm{Hg}$ studies.

\section{Environmental Setting and Mercury Cycling}

Both the New York and South Carolina study basins are in areas that are considered to be biologically sensitive to $\mathrm{Hg}$ from atmospheric sources, in that conditions are favorable for efficient conversion of inorganic $\mathrm{Hg}$ from atmospheric deposition to methylmercury ( $\mathrm{MeHg}$, the organic and bioavailable form of $\mathrm{Hg}$ ) and its transport to adjacent streams (Evers and others, 2007; Bradley and others, 2011). MeHg is a potent neurotoxin that enters the base of aquatic food webs and is concentrated to increasingly higher levels by consumers. Thus, conversion of inorganic $\mathrm{Hg}$ to $\mathrm{MeHg}$ (a process known as methylation) is a critical step because it greatly increases the bioavailability of $\mathrm{Hg}$.

$\mathrm{Hg}$ transported by the atmosphere and deposited on the landscape is thought to be the dominant source of $\mathrm{Hg}$ to the study basins (New York State Department of Environmental Conservation, 2008; South Carolina Department of Health and Environmental Control, 2010); Hg in wet atmospheric deposition (rain and snow) is moderate to high in the two basins relative to the rest of the Nation (National Atmospheric Deposition Program, 2010).

Land use/land cover in the New York and South Carolina basins is mostly forested and woody wetland ("swamp"), and these types of land cover are known to be important in methylation of $\mathrm{Hg}$ (Driscoll and others, 1994; Hurley and others, 1995; St. Louis and others, 1994, 1996; U.S. Environmental Protection Agency, 1997; Kolka and others, 1999; Krabbenhoft and others, 1999; Chumchal and others, 2008; Brigham and others, 2009; Scudder and others, 2009). 


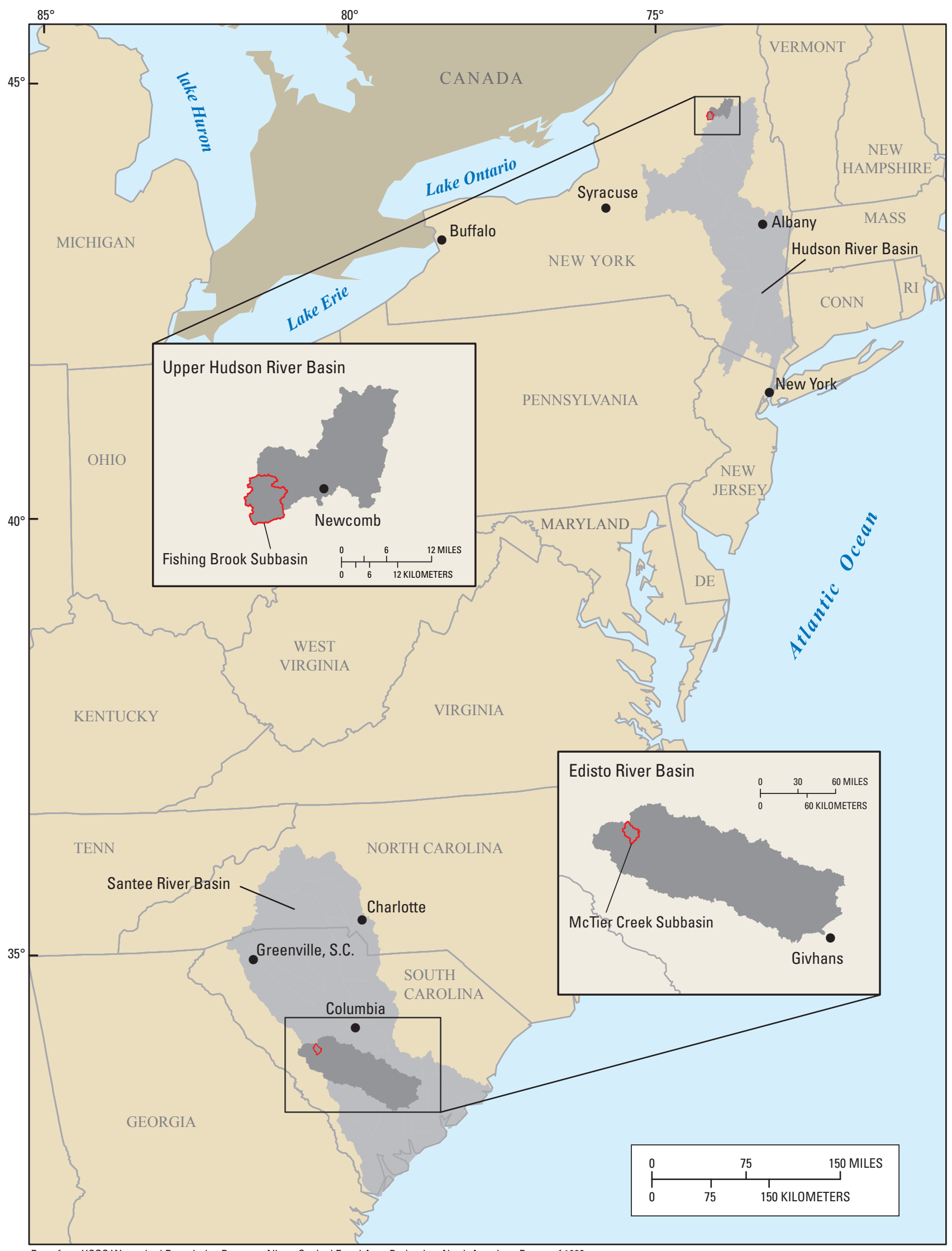

Base from USGS Watershed Boundaries Dataset. Albers Conical Equal Area Projection, North American Datum of 1983.

Figure 1. Locations of New York and South Carolina study basins. 
Indeed, fish from the New York and South Carolina basins are known to have $\mathrm{Hg}$ concentrations of concern for consumption by humans and wildlife (Yeardley and others, 1998; U.S. Environmental Protection Agency, 2001a, 2001b; Evers and others, 2007; New York State Department of Environmental Conservation, 2008; Simonin and others, 2009; Glover and others, 2010; South Carolina Department of Health and Environmental Control, 2010; National Oceanic and Atmospheric Administration and South Carolina Department of Natural Resources, 2011; New York State Department of Health, 2011; South Carolina Department of Health and Environmental Control, 2011). Hg in top-predator fish is particularly high in the Edisto River of the Santee River Basin, South Carolina. In a study of top-predator fish from streams across the Nation, concentrations of $\mathrm{Hg}$ in a composite sample of largemouth bass (Micropterus salmoides) from the Edisto River ranked above the $95^{\text {th }}$ percentile, and a composite sample of largemouth bass from the North Fork Edisto River near Fairview Crossroads, S.C., contained 1.80 micrograms per gram $(\mu \mathrm{g} / \mathrm{g})$ wet weight $\mathrm{Hg}$, a concentration that was exceeded only by a composite sample of fish from a stream in a mined basin (Bauch and others, 2009; Scudder and others, 2009).

Several candidate basins were explored for inclusion at the outset of this study, and the Upper Hudson River Basin and Edisto River Basin were selected because each included regions, such as the Adirondacks in the Hudson and Coastal Plain in the Edisto, where high MeHg concentrations had been identified previously in surface waters and biota. Once these basins were identified for study, a smaller subbasin within each was selected for intensive study based on the premise that subbasins in the range of 50 to $100 \mathrm{~km}^{2}$ would be most appropriate for investigations focused on biogeochemical processes and bioaccumulation. Factors such as the presence of an existing streamgage or an appropriate streamgaging location, accessibility throughout the year, and landscape representativeness of the larger basin also were considered in subbasin selection. The two selected subbasins, Fishing Brook in New York and McTier Creek in South Carolina, are similar in size but differ in climate, atmospheric $\mathrm{Hg}$ loading, land use/land cover, aquatic species composition and community structure, and hydrology. The numerous synoptic sites sampled during the study were selected primarily based on representing a range of influence of landscape elements such as riparian wetlands, forested uplands, and lakes/ponds that were assumed likely to affect $\mathrm{MeHg}$ concentrations in surface water and biota. Reconnaissance included a total of 54 sites, 28 in New York and 26 in South Carolina; although most of the subsequent sampling was done at a subset of these sites. All sites are listed in table 1 .

\section{Sources of Environmental Setting Data}

Environmental setting data for the sites described in this report were compiled from a variety of sources, which are listed in table 2. Total $\mathrm{Hg}$ concentrations and deposition were monitored at two National Atmospheric Deposition Program Mercury Deposition Network (NADP-MDN) monitoring locations near each study basin: Huntington Wildlife Forest (NY20) and Congaree Swamp (SC19) (National Atmospheric Deposition Program, 2010a; table 3). As part of NADP-MDN monitoring, precipitation samples were collected weekly and analyzed for total $\mathrm{Hg}$ using established protocols to quantify weekly precipitation and wet deposition loads of $\mathrm{Hg}$ at both sites (National Atmospheric Deposition Program, 2006, 2010b; Latysch and Wetherbee, 2007). The Parameterelevation Regressions on Independent Slopes Model (PRISM) was used for this investigation to determine basin-wide mean annual precipitation for the Edisto and Hudson River Basins. The PRISM is a system that uses point measurements of precipitation, temperature, and other climatic factors from across the United States to produce continuous, regularly spaced, digital-grid estimates of monthly, annual, and event-based climatic parameters (Daly and others, 1994, 2002; Daly, 2006; National Water and Climate Center, 2010; PRISM Climate Group, 2010). In a method modified from Latysch and Wetherbee (2011), PRISM grid estimates of mean annual precipitation were applied to mean annual $\mathrm{Hg}$ concentrations at the two NADP-MDN monitoring locations to produce mean annual wet-deposition estimates for total $\mathrm{Hg}$ in both basins (table 4). Data for atmospheric dry deposition of $\mathrm{Hg}$ are not available but dry deposition can be significant (Miller and others, 2005; Sakata and others, 2006; Choi and others, 2008; Risch and others, 2011). Mean air temperatures for summer and winter near the primary USGS sampling sites were estimated using data from the National Climatic Data Center (NCDC) (National Climatic Data Center, 2011a) for nearby NCDC sites (table 4). 
Table 1. Map numbers and complete site names with basic basin characteristics for streams sampled in New York and South Carolina for U.S. Geological Survey mercury studies, 2005-09.

[USGS, U.S. Geological Survey; $\mathrm{km}^{2}$, square kilometer; m, meter; km, kilometer; nd, no data; latitude and longitude are in decimal degrees, referenced to the North American Datum of 1927; elevation at basin outlet is from the National Elevation Dataset, referenced to the North American Vertical Datum of 1988; NADP-MDN, National Atmospheric Deposition Program-Mercury Deposition Network; NADP-MDN site NY20: latitude and longitude are 43.9731 and -74.2231, respectively; NADP-MDN site SC19: latitude and longitude are 33.8145 and -80.7809 , respectively; primary sampling sites are shown in bold]

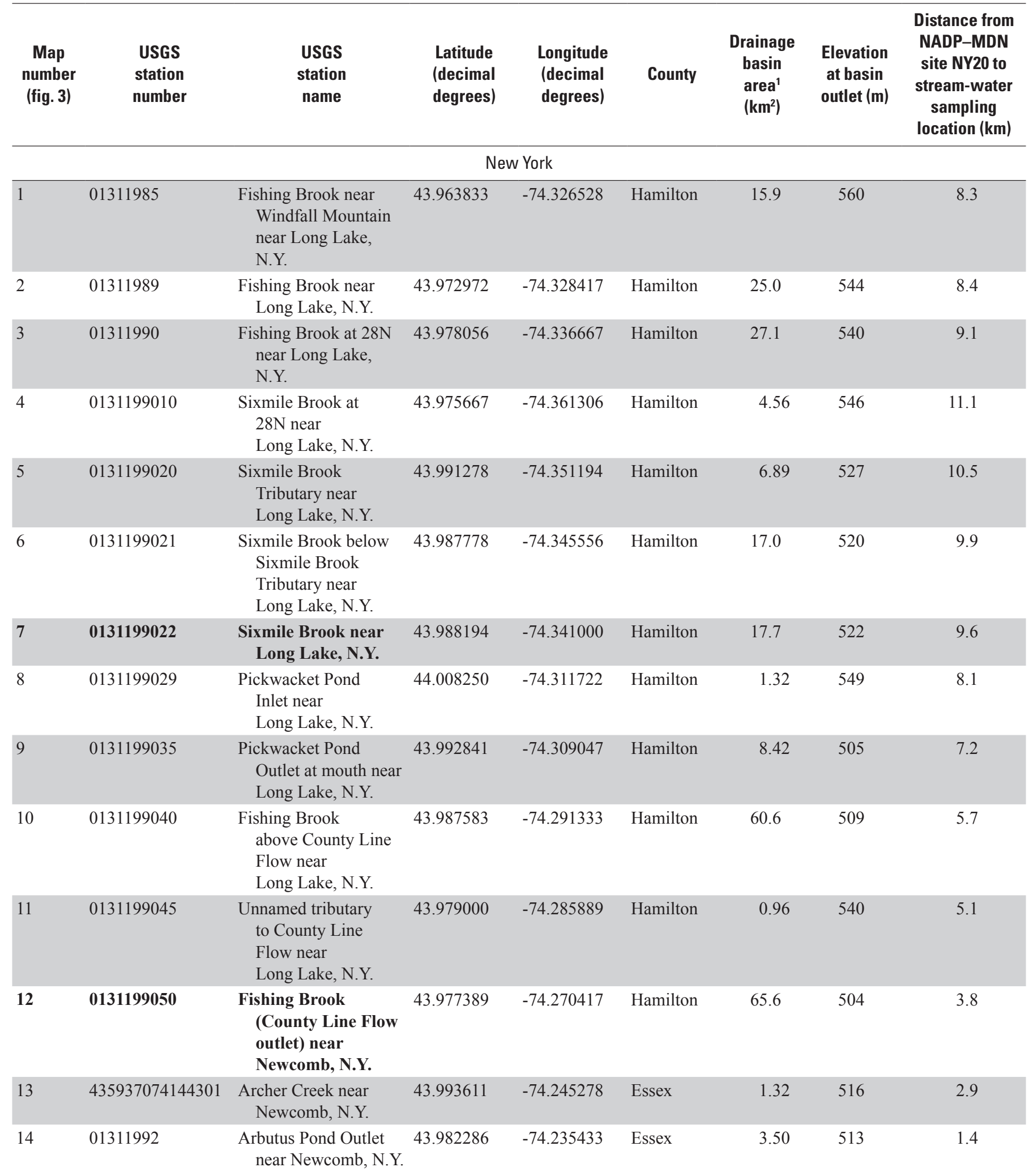


Table 1. Map numbers and complete site names with basic basin characteristics for streams sampled in New York and South Carolina for U.S. Geological Survey mercury studies, 2005-09.-Continued

[USGS, U.S. Geological Survey; $\mathrm{km}^{2}$, square kilometer; m, meter; km, kilometer; nd, no data; latitude and longitude are in decimal degrees, referenced to the North American Datum of 1927; elevation at basin outlet is from the National Elevation Dataset, referenced to the North American Vertical Datum of 1988; NADP-MDN, National Atmospheric Deposition Program-Mercury Deposition Network; NADP-MDN site NY20: latitude and longitude are 43.9731 and -74.2231, respectively; NADP-MDN site SC19: latitude and longitude are 33.8145 and -80.7809 , respectively; primary sampling sites are shown in bold]

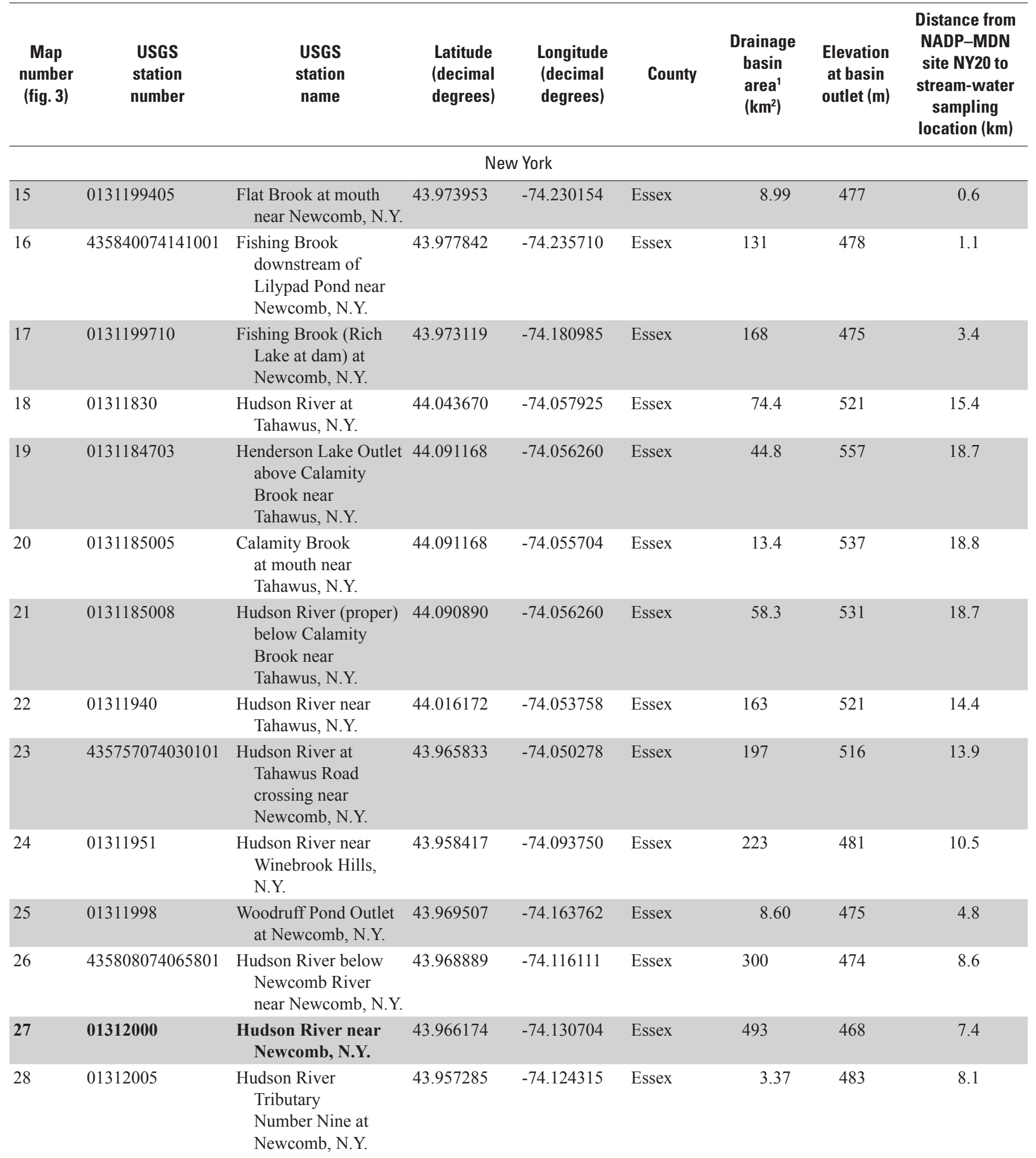


Table 1. Map numbers and complete site names with basic basin characteristics for streams sampled in New York and South Carolina for U.S. Geological Survey mercury studies, 2005-09._-Continued

[USGS, U.S. Geological Survey; km², square kilometer; m, meter; km, kilometer; nd, no data; latitude and longitude are in decimal degrees, referenced to the North American Datum of 1927; elevation at basin outlet is from the National Elevation Dataset, referenced to the North American Vertical Datum of 1988; NADP-MDN, National Atmospheric Deposition Program-Mercury Deposition Network; NADP-MDN site NY20: latitude and longitude are 43.9731 and -74.2231, respectively; NADP-MDN site SC19: latitude and longitude are 33.8145 and -80.7809 , respectively; primary sampling sites are shown in bold]

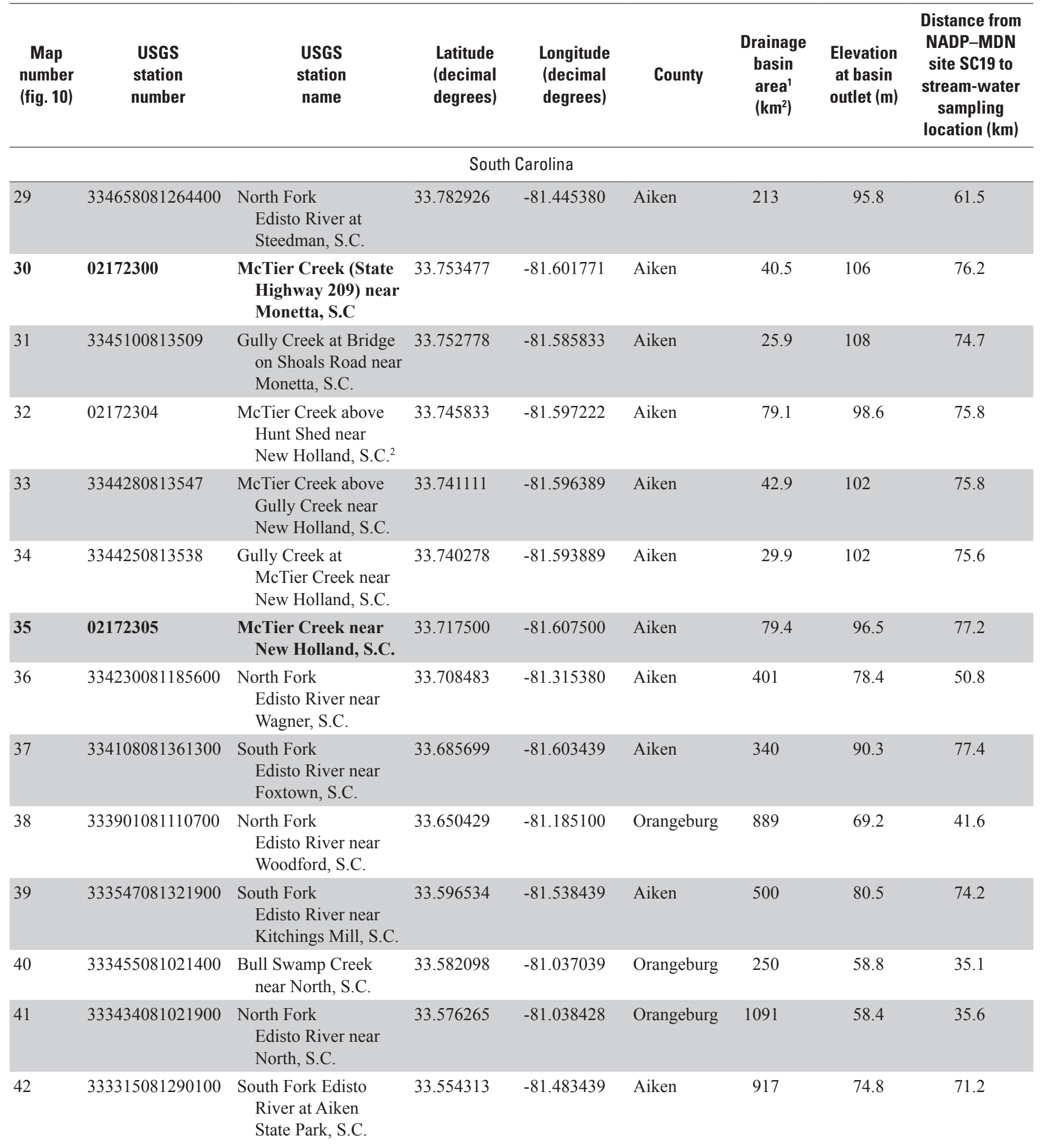


Table 1. Map numbers and complete site names with basic basin characteristics for streams sampled in New York and South Carolina for U.S. Geological Survey mercury studies, 2005-09.-Continued

[USGS, U.S. Geological Survey; km², square kilometer; m, meter; km, kilometer; nd, no data; latitude and longitude are in decimal degrees, referenced to the North American Datum of 1927; elevation at basin outlet is from the National Elevation Dataset, referenced to the North American Vertical Datum of 1988; NADP-MDN, National Atmospheric Deposition Program-Mercury Deposition Network; NADP-MDN site NY20: latitude and longitude are 43.9731 and -74.2231, respectively; NADP-MDN site SC19: latitude and longitude are 33.8145 and -80.7809 , respectively; primary sampling sites are shown in bold]

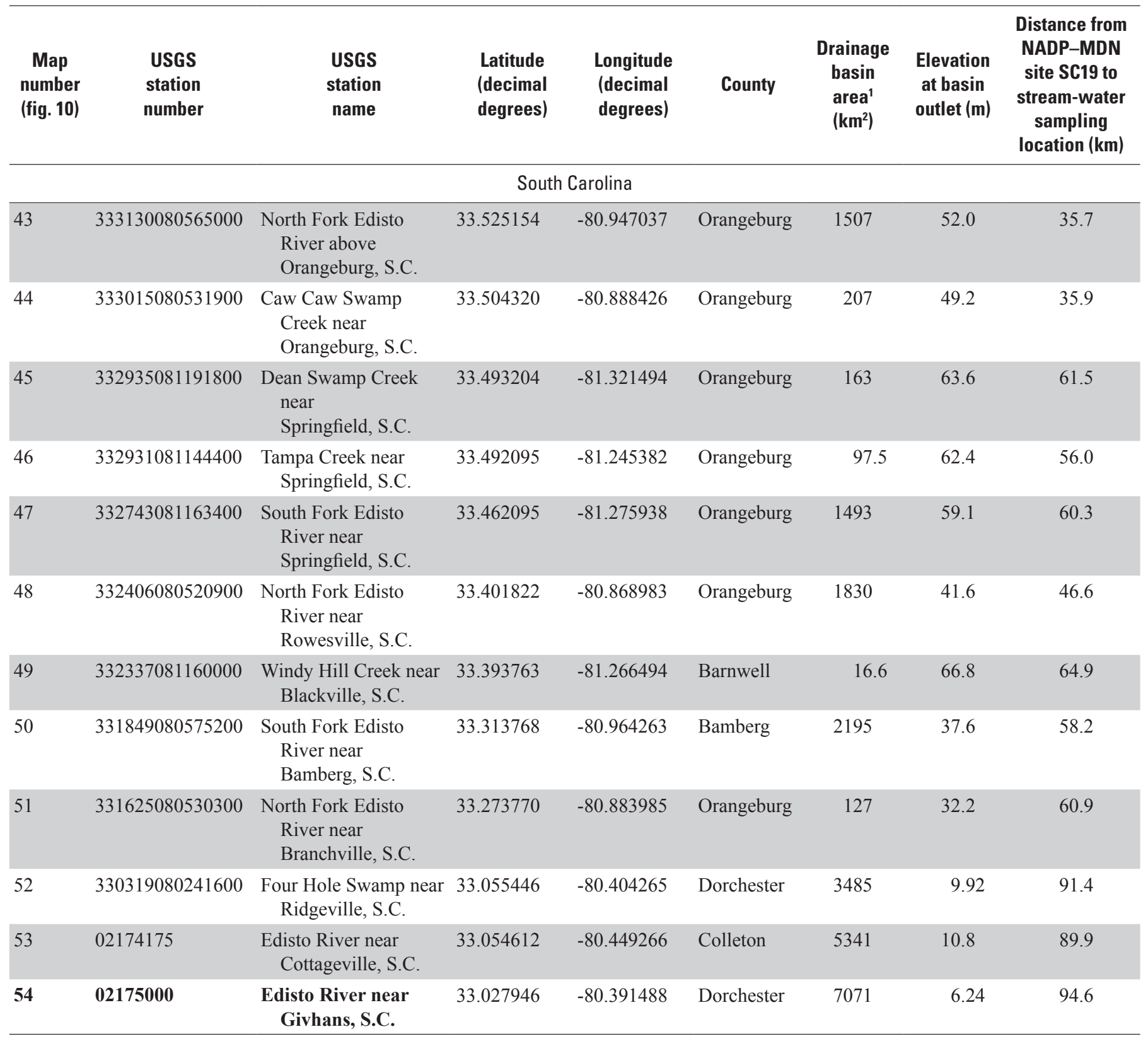

${ }^{1}$ Drainage basin areas for gaged sites were derived from delineations made as part of the process of determining land cover area in this study. In some cases, the drainage basin areas differed from those shown for these sites in the USGS National Water Information System (NWIS) and published in annual streamflow reports. Some of the papers and reports written as part of this study have used the NWIS values of $65.3 \mathrm{~km}^{2}$ for Site 12 and $497.3 \mathrm{~km}^{2}$ for Site $27,40.4 \mathrm{~km}^{2}$ for Site $30,79.5 \mathrm{~km}^{2}$ for Site 35, and $7070.7 \mathrm{~km}^{2}$ for Site 54 .

${ }^{2}$ Site 32 is about 800 meters upstream of site 35 . 
Table 2. Sources of environmental-setting data for streams sampled in New York and South Carolina for U.S. Geological Survey mercury studies, 2005-09.

\begin{tabular}{|c|c|c|}
\hline Data & Data source & Reference \\
\hline Atmospheric mercury deposition & $\begin{array}{l}\text { Mercury Deposition Network-National } \\
\text { Atmospheric Deposition Program } \\
\text { (MDN-NADP) }\end{array}$ & $\begin{array}{l}\text { National Atmospheric Deposition Program, } \\
\text { 2010b (http://nadp.sws.uiuc.edu/mdn) }\end{array}$ \\
\hline Drainage basin areas & Watershed Boundary Dataset & $\begin{array}{l}\text { Natural Resources Conservation Service, } 2010 \\
\text { (http://www.ncgc.nrcs.usda.gov/products/ } \\
\text { datasets/watershed/) }\end{array}$ \\
\hline Elevation, 10 meter resolution & $\begin{array}{l}\text { National Elevation Dataset (NED)- } \\
\text { Digital Elevation Model (DEM) }\end{array}$ & $\begin{array}{l}\text { U.S. Geological Survey, 2010a } \\
\text { (http://ned.usgs.gov/) }\end{array}$ \\
\hline $\begin{array}{l}\text { Flow-path length, flow distance to } \\
\text { channel network }\end{array}$ & $\begin{array}{l}\text { System for Automated Geoscientific } \\
\text { Analysis-Geographic Information } \\
\text { System software (SAGA-GIS) }\end{array}$ & $\begin{array}{l}\text { System for Automated Geoscientific Analysis } \\
\text { Geographic Information System, } 2007 \\
\text { (http://www.saga-gis.org/en/index.html) }\end{array}$ \\
\hline Frost-free period & Freeze/frost maps & $\begin{array}{l}\text { National Climatic Data Center, 2011b } \\
\text { (http://www.ncdc.noaa.gov/img/climatel } \\
\text { freezefrost/Freezefree32F.pdf) }\end{array}$ \\
\hline $\begin{array}{l}\text { Hydric soils, organic-matter content, } \\
\text { KSAT1 }\end{array}$ & $\begin{array}{l}\text { U.S. Department of Agriculture Soil Survey } \\
\text { (SSURGO) }\end{array}$ & $\begin{array}{l}\text { Natural Resources Conservation Service, } 2011 \\
\text { (http://soils.usda.gov/survey/geography/ } \\
\text { ssurgo/) }\end{array}$ \\
\hline Land use/land cover & $\begin{array}{l}\text { National Land Cover Data for } 2001 \\
\text { (NLCD01) }\end{array}$ & $\begin{array}{l}\text { Yang and others, 2002; Homer and others, 2004; } \\
\text { http://www.mrlc.gov/nlcd2001.php }\end{array}$ \\
\hline Precipitation (basin-wide means) & $\begin{array}{l}\text { Parameter-elevation Regressions on } \\
\text { Independent Slopes Model (PRISM) }\end{array}$ & $\begin{array}{l}\text { PRISM Climate Group, } 2010 \text { (http://prism. } \\
\text { oregonstate.edu; National Water and Climate } \\
\text { Center, } 2010 \text { (http://www.wcc.nrcs.usda.gov/ } \\
\text { climate/prism.html) }\end{array}$ \\
\hline Satellite images & $\begin{array}{l}\text { U.S. Department of Agriculture-Farm } \\
\text { Service Agency, National Agriculture } \\
\text { Imagery Program (New York only), } \\
\text { provided by Environmental Systems } \\
\text { Research Institute }\end{array}$ & $\begin{array}{l}\text { Environmental Systems Research Institute, } 2008 \\
\quad \text { (http://www.arcgis.com/home/item.html?id=5f } \\
\text { 5f6b9ee5b4483f9767b118b7b99323) }\end{array}$ \\
\hline Satellite images & $\begin{array}{l}\text { AEX Aerials Maps \& Data (South Carolina } \\
\text { only), provided by Environmental } \\
\text { Systems Research Institute }\end{array}$ & $\begin{array}{l}\text { Environmental Systems Research Institute, } \\
2007 \text { (http://www.aerials-gis.com/AEX_Sitel } \\
\text { GIS_System.html) }\end{array}$ \\
\hline Stream network base maps & National Hydrography Dataset & $\begin{array}{l}\text { U.S. Geological Survey, 2010b } \\
\text { (http://nhd.usgs.gov/) }\end{array}$ \\
\hline Streamflow & National Water Information System (NWIS) & $\begin{array}{l}\text { U.S. Geological Survey, 2010c (http://waterdata. } \\
\text { usgs.gov/nwis/measurements) }\end{array}$ \\
\hline Temperature, air (seasonal means) & National Climatic Data Center (NCDC) & $\begin{array}{l}\text { National Climatic Data Center, 2011a } \\
\text { (http://www.ncdc.noaa.gov/oa/climate/ } \\
\text { stationlocator.html) }\end{array}$ \\
\hline Temperature, water & $\begin{array}{l}\text { Water-Data Reports, National Water } \\
\text { Information System (NWIS) }\end{array}$ & $\begin{array}{l}\text { U.S. Geological Survey, 2010c (http://wdr.water. } \\
\text { usgs.gov/; http://waterdata.usgs.gov/nwis/ } \\
\text { measurements) }\end{array}$ \\
\hline Wetness index, topographic & $\begin{array}{l}\text { System for Automated Geoscientific } \\
\text { Analysis-Geographic Information } \\
\text { System software (SAGA-GIS) }\end{array}$ & $\begin{array}{l}\text { System for Automated Geoscientific Analysis } \\
\text { Geographic Information System, } 2007 \\
\text { (http://www.saga-gis.org/en/index.html) }\end{array}$ \\
\hline Wetland cover, detailed & $\begin{array}{l}\text { Wetlands in the Greater Upper Hudson } \\
\text { River Watershed Dataset } \\
\text { (New York only) }\end{array}$ & $\begin{array}{l}\text { New York State Adirondack Park Agency, } 2007 \\
\text { (http://www.apa.state.ny.us/gis/index.html) }\end{array}$ \\
\hline Wetland cover, detailed & $\begin{array}{l}\text { National Wetlands Inventory Dataset } \\
\text { (South Carolina only) }\end{array}$ & $\begin{array}{l}\text { U.S. Fish and Wildlife Service, } 2010 \\
\text { (http://www.fws.gov/wetlands/) }\end{array}$ \\
\hline
\end{tabular}

${ }^{1}$ KSAT, areal-weighted saturated hydraulic conductivity. 
Table 3. Selected locations in the National Atmospheric Deposition Program-Mercury Deposition Network (NADP-MDN) used to estimate atmospheric wet deposition of total mercury in the Hudson River Basin, New York, and the Edisto River Basin, South Carolina.

\begin{tabular}{llllccc}
\hline \multicolumn{1}{c}{ Study area } & $\begin{array}{c}\text { NADP-MDN } \\
\text { monitoring } \\
\text { location }\end{array}$ & \multicolumn{1}{c}{ Location name } & Period of record & $\begin{array}{c}\text { Latitude } \\
\text { (decimal } \\
\text { degrees) }\end{array}$ & $\begin{array}{c}\text { Longitude } \\
\text { (decimal } \\
\text { degrees) }\end{array}$ & $\begin{array}{c}\text { Elevation } \\
\text { at location } \\
\text { (meters) }\end{array}$ \\
\hline Hudson River & NY20 & Huntington Wildlife Forest & $12 / 10 / 1999-$ present & 43.9731 & -74.2231 \\
Edisto River & SC19 & Congaree Swamp & $3 / 5 / 1996-$ present & 33.8145 & -80.7809 \\
\hline
\end{tabular}

Table 4. Mean air temperature, precipitation, and atmospheric mercury data for primary stream basins sampled in New York and South Carolina for U.S. Geological Survey mercury studies, 2005-09.

$\left[{ }^{\circ} \mathrm{C}\right.$, degrees Celsius; $\mathrm{mm}$, millimeter; $\mu \mathrm{g} / \mathrm{m}^{2} / \mathrm{yr}$, microgram per square meter per year; nd, no data; data in this table were obtained from several sources: air temperature data were summarized from National Climatic Data Center (NCDC) datasets for nearest sites; NCDC site 305714 at Newcomb, N.Y.: latitude and longitude are 43.97 and -74.22, respectively; NCDC site 380074 at Aiken, S.C.: latitude and longitude are 33.50 and -81.70, respectively; National Climatic Data Center, 2011a); atmospheric mercury values are from the National Atmospheric Deposition Program-Mercury Deposition Network (NADP-MDN, National Atmospheric Deposition Program, 2010) and are precipitation-weighted values; precipitation values used for weighting were basin-wide means derived from Parameter-elevation Regressions on Independent Slopes Model (PRISM) climate mapping system (PRISM Climate Group, 2010); location information for NADP-MDN sites NY20 and SC19 is provided in table 1.]

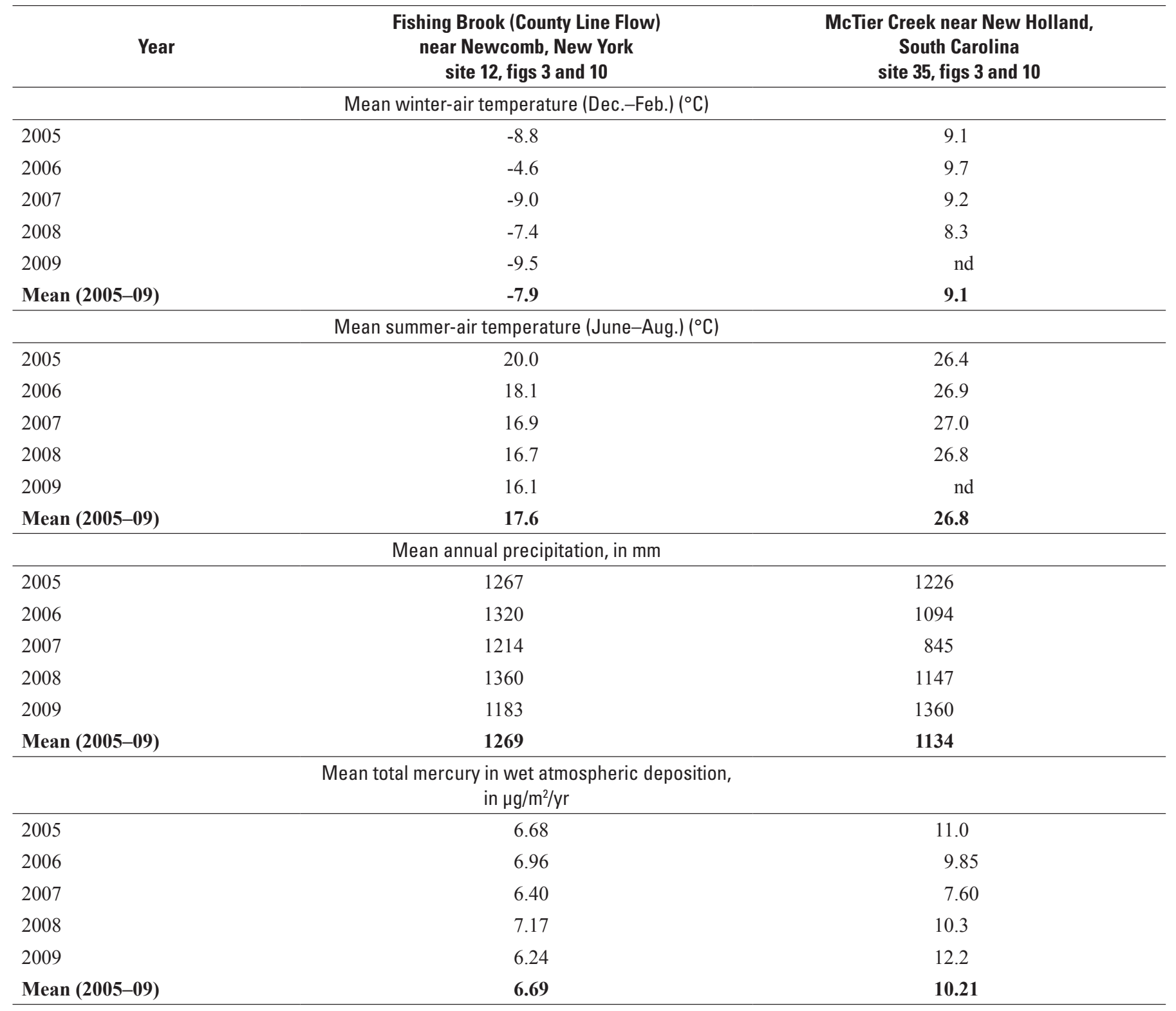


Drainage basin areas were determined using the Watershed Boundary Dataset (Natural Resources Conservation Service, 2010), field checked, and adjusted when necessary. Drainage area and site elevations are shown in table 1. Elevations were obtained from the 10 m USGS National Elevation Dataset (U.S. Geological Survey, 2010a). Several elevationderived descriptive parameters were derived using System for Automated Geoscientific Analysis (SAGA) geographic information system (GIS), and these parameters included topographic wetness index, flow-path length, overland flow distance and horizontal flow distance to channel network, altitude above channel network, and riparian area and width (System for Automated Geoscientific Analysis Geographic Information System, 2007). Topographic wetness index is a ratio of natural upslope contributing area to slope and is used as a measure of soil wetness. Flow-path length is an average of flow lengths, or distances, from points in the basin along the direction of flow to the basin outlet; the flow path is defined using a multiflow direction algorithm. Overland flow distance is an average value that represents overland and shallow subsurface flow distances to the nearest point on the stream channel network, and it is also referred to as 'Hydrologic Transport Distance' in Riva-Murray and others (2011). Horizontal flow distance is the Euclidean distance from each point in the basin to the nearest point on the stream. Riparian area is the area within $0.65 \mathrm{~m}$ elevation of each stream point, excluding open water. The Natural Resources Conservation Service Soil Survey Geographic (SSURGO) database was used for estimating areas of hydric soils, organic-matter content, and areal-weighted saturated hydraulic conductivity as shown in appendix 1 for New York and appendix 2 for South Carolina (Natural Resources Conservation Service, 2011). Land use/land cover data for all basins, provided in table 5, were based on the National Land Cover Dataset (NLCD) for 2001 (NLCD01) (Homer and others, 2004; Yang and others, 2002). Additional detailed wetland coverage, using a different method of delineation and based on aerial photogrammetry, was from the New York State Adirondack Park Agency (APA) for New York basins and from the U.S. Fish and Wildlife Service National Wetlands Inventory (NWI) for South Carolina; these data are summarized in table 5 , and details are provided in appendixes 1 and 2 (New York State Adirondack Park Agency, 2007; U.S. Fish and Wildlife Service, 2010). Wetland percentages for sites may differ between NLCD01 and either APA or NWI due to methodological differences.

Stream network base maps were created using the USGS National Hydrography Dataset (U.S. Geological Survey, 2010b). Streamflow (discharge) and water temperature data at USGS streamflow-gaging stations are summarized in tables 6 and 7, and all data are available in the USGS National Water Information System (U.S. Geological Survey, 2010c) and (or) as water-data reports, available at http://wdr.water.usgs.gov/.

Figures provided in this report include photographs and maps (at several scales) of the study areas. Photographs show conditions at or near sampling sites during spring or summer when most biological samples were collected. Location of stream-basin boundaries, USGS streamflow-gaging stations, and sampling sites are shown within the context of their respective larger stream basins and their location in the United States. Maps showing detailed wetland coverage for New York streams are from the Wetlands in the Greater Upper Hudson River Watershed dataset (New York State Adirondack Park Agency, 2007), and those for South Carolina streams are from the NWI dataset (U.S. Fish and Wildlife Service, 2010). Satellite images for figures 7 and 13 were provided by the Environmental Systems Research Institute (ESRI); images for the Fishing Brook/Upper Hudson River were taken by the U.S. Department of Agriculture-Farm Service Agency, National Agriculture Imagery Program (NAIP) at 1-m resolution on October 11, 2008 (Environmental Systems Research Institute, 2008); and images for the McTier Creek/Edisto River were taken by Aerials Express at 0.5-m resolution on March 15, 2007 (Environmental Systems Research Institute, 2007).

\section{Environmental Setting of New York Streams}

The New York streams sampled for the 2005-09 NAWQA Hg studies are in the Upper Hudson River Basin (fig. 1, table 1), which is defined here as the portion of the basin upstream of Hudson River near Newcomb, N.Y. (Site 27). Reconnaissance sampling was conducted throughout the Upper Hudson River Basin during 2005 (one of these sites, Site 28, was slightly downstream of the defined basin boundary at Site 27), after which more intensive sampling (2007-09) focused in the Fishing Brook Subbasin, in the western-most headwaters of the Upper Hudson River Basin. Seventeen sites were located throughout the Fishing Brook Subbasin and include locations on Fishing Brook, Sixmile Brook, several pond/lake inlets and outlets, and an un-named tributary. Elevations in the Upper Hudson Basin range from $468 \mathrm{~m}$ above sea level near Newcomb (Site 27) to 1,624 m above sea level at Mount Marcy, the highest point in New York State. The Fishing Brook sites range in elevation from 475 to $560 \mathrm{~m}$ above sea level (table 1). Topography is highly heterogeneous, across both the entire Upper Hudson River Basin and the Fishing Brook Subbasin, with relatively flat to steep slopes. Median basin slope ranges from 3.6 percent slope at Hudson River Tributary Number Nine at Newcomb, N.Y. (Site 28) to 31.8 percent slope at Calamity Brook (Site 20) (appendix 1). With the exception of Hudson River Tributary Number Nine at Newcomb, N.Y. (Site 28), sample sites in the Upper Hudson River Basin have predominantly ( $>70$ percent) forested upland land cover. There is a wide range of wetland amount across sites ( 0 to 14 percent). For Site 28 only, ground truthing showed erroneously high NLCD01 wetland values that may be incorrectly categorized forested land in this small basin $\left(3.37 \mathrm{~km}^{2}\right)$, so NLCD01 wetland and forested values are not included in table 5. The amount of open water (lakes and ponds, both natural and man-made) also varies among the subbasins studied in the Upper Hudson River Basin, from 0 to 15 percent. 
Table 5. Land use/land cover data for streams sampled in New York and South Carolina for U.S. Geological Survey mercury studies, $2005-09$.

[Land use/land cover data are based on the National Land Cover Dataset for 2001 (NLCD01; Yang and others, 2002; Homer and others, 2004) for basins that were delineated using a geographic information system. More detailed wetland data, using a separate method of delineation, are included: APA wetland values for New York streams are from the Wetlands in the Greater Upper Hudson River Watershed dataset (New York State Adirondack Park Agency, 2007) and National Wetlands Inventory (NWI) wetland values for South Carolina streams are from the NWI dataset (U.S. Fish and Wildlife Service, 2010); nd, no data. Additional detailed land-use data are provided in appendixes 1 and 2. Primary sampling sites shown in bold]

\begin{tabular}{|c|c|c|c|c|c|c|c|c|c|c|c|c|c|c|c|}
\hline \multirow{3}{*}{$\begin{array}{c}\text { Map } \\
\text { number } \\
\text { (fig. 3) }\end{array}$} & \multicolumn{15}{|c|}{ Land use/land cover (percent of basin area) } \\
\hline & \multicolumn{4}{|c|}{ Forest } & \multicolumn{4}{|c|}{ Wetland } & \multirow[b]{2}{*}{$\begin{array}{c}\text { NLCD01 } \\
\text { Open } \\
\text { water }\end{array}$} & \multirow[b]{2}{*}{$\begin{array}{l}\text { APA } \\
\text { Open } \\
\text { water }\end{array}$} & \multirow[b]{2}{*}{$\begin{array}{l}\text { NLCD01 } \\
\text { Shrubland }\end{array}$} & \multirow[b]{2}{*}{$\begin{array}{c}\text { NLCD01 } \\
\text { Herbaceous } \\
\text { upland }\end{array}$} & \multirow[b]{2}{*}{$\begin{array}{c}\text { NLCD01 } \\
\text { Agriculture }\end{array}$} & \multirow[b]{2}{*}{$\begin{array}{c}\text { NLCD01 } \\
\text { Developed* }\end{array}$} & \multirow[b]{2}{*}{$\begin{array}{l}\text { NLCD01 } \\
\text { Barren }\end{array}$} \\
\hline & $\begin{array}{l}\text { NLCD01 } \\
\text { Deciduous } \\
\text { forest }\end{array}$ & $\begin{array}{c}\text { NLCD01 } \\
\text { Evergreen } \\
\text { forest }\end{array}$ & $\begin{array}{c}\text { NLCD01 } \\
\text { Mixed } \\
\text { forest }\end{array}$ & $\begin{array}{c}\text { NLCD01 } \\
\text { Total } \\
\text { forest }\end{array}$ & $\begin{array}{l}\text { NLCD01 } \\
\text { Woody } \\
\text { wetland }\end{array}$ & $\begin{array}{c}\text { NLCD01 } \\
\text { Herbaceous } \\
\text { wetland }\end{array}$ & $\begin{array}{c}\text { NLCD01 } \\
\text { Total } \\
\text { wetland }\end{array}$ & $\begin{array}{c}\text { APA } \\
\text { Total } \\
\text { wetland }\end{array}$ & & & & & & & \\
\hline \multicolumn{16}{|c|}{ New York } \\
\hline 1 & 52.12 & 31.21 & 10.62 & 93.95 & 4.74 & 0.82 & 5.56 & 4.41 & 0.16 & 0.49 & 0.16 & 0 & 0 & 0 & 0 \\
\hline 2 & 48.08 & 35.54 & 10.26 & 93.89 & 4.87 & 0.62 & 5.49 & 5.18 & 0.10 & 0.41 & 0.21 & 0 & 0 & 0.10 & 0 \\
\hline 3 & 47.46 & 34.74 & 9.86 & 92.06 & 5.55 & 0.86 & 6.41 & 5.84 & 1.05 & 1.15 & 0.29 & 0 & 0 & 0.19 & 0 \\
\hline 4 & 40.34 & 41.48 & 11.36 & 93.18 & 5.11 & 0.57 & 5.68 & 6.82 & 1.14 & 0.57 & 0 & 0 & 0 & 0.57 & 0 \\
\hline 5 & 72.56 & 11.28 & 6.39 & 90.23 & 7.14 & 1.13 & 8.27 & 6.77 & 0.75 & 1.13 & 0.75 & 0 & 0 & 0 & 0 \\
\hline 6 & 51.22 & 25.99 & 6.99 & 84.19 & 11.85 & 1.82 & 13.68 & 13.22 & 0.91 & 0.61 & 0.46 & 0 & 0 & 0.76 & 0 \\
\hline 7 & 51.39 & 25.40 & 7.15 & 83.94 & 11.82 & 2.04 & 13.87 & 12.99 & 1.02 & 0.58 & 0.44 & 0 & 0 & 0.73 & 0 \\
\hline 8 & 76.47 & 13.73 & 5.88 & 96.08 & 1.96 & 0 & 1.96 & 0 & 0 & 0 & 1.96 & 0 & 0 & 0 & 0 \\
\hline 9 & 73.23 & 5.54 & 4.31 & 83.08 & 4.62 & 0.62 & 5.23 & 4.62 & 11.4 & 10.5 & 0.62 & 0 & 0 & 0 & 0 \\
\hline 10 & 53.03 & 26.37 & 7.48 & 86.88 & 8.29 & 1.20 & 9.49 & 8.63 & 2.35 & 2.18 & 0.51 & 0.21 & 0 & 0.64 & 0 \\
\hline 11 & 64.86 & 21.62 & 13.51 & 100.00 & 0 & 0 & 0 & 0 & 0 & 0 & 0 & 0 & 0 & 0 & 0 \\
\hline 12 & 53.75 & 25.30 & 7.26 & 86.31 & 8.17 & 1.14 & 9.31 & 8.25 & 3.00 & 2.68 & 0.47 & 0.20 & 0 & 0.71 & 0 \\
\hline 13 & 56.86 & 13.73 & 21.57 & 92.16 & 5.88 & 0.00 & 5.88 & 9.80 & 0 & 0 & 0.00 & 0 & 0 & 0 & 0 \\
\hline 14 & 43.70 & 14.81 & 16.30 & 74.81 & 10.37 & 0.00 & 10.37 & 4.44 & 14.8 & 14.1 & 0.00 & 0 & 0 & 0 & 0 \\
\hline 15 & 65.13 & 16.71 & 6.63 & 88.47 & 8.93 & 1.44 & 10.37 & 7.20 & 0.00 & 0.58 & 0.29 & 0 & 0 & 0.86 & 0 \\
\hline 16 & 55.61 & 18.78 & 7.22 & 81.61 & 10.32 & 1.20 & 11.52 & 7.61 & 5.90 & 5.35 & 0.47 & 0.10 & 0 & 0.41 & 0 \\
\hline 17 & 56.29 & 18.07 & 7.50 & 81.87 & 9.81 & 1.14 & 10.95 & 7.29 & 6.18 & 5.70 & 0.37 & 0.08 & 0.03 & 0.52 & 0 \\
\hline 18 & 21.84 & 48.38 & 17.49 & 87.70 & 3.97 & 1.11 & 5.09 & 2.61 & 3.38 & 3.20 & 3.17 & 0.24 & 0 & 0.45 & 0.07 \\
\hline 19 & 23.64 & 56.47 & 13.82 & 93.93 & 2.25 & 0.06 & 2.31 & 2.89 & 3.24 & 2.95 & 0.35 & 0.12 & 0 & 0 & 0 \\
\hline 20 & 4.05 & 56.76 & 34.56 & 95.37 & 2.32 & 0 & 2.32 & 2.12 & 0.19 & 0.00 & 2.12 & 0 & 0 & 0 & 0 \\
\hline 21 & 19.11 & 56.62 & 18.58 & 94.31 & 2.27 & 0.04 & 2.31 & 2.71 & 2.53 & 2.27 & 0.80 & 0.09 & 0 & 0 & 0 \\
\hline 22 & 22.07 & 49.35 & 16.63 & 88.06 & 4.52 & 0.78 & 5.30 & 2.93 & 2.68 & 2.11 & 3.17 & 0.25 & 0 & 0.38 & 0.17 \\
\hline 23 & 26.83 & 44.68 & 15.75 & 87.26 & 5.62 & 0.80 & 6.42 & 4.28 & 2.88 & 2.27 & 2.64 & 0.21 & 0 & 0.46 & 0.14 \\
\hline 24 & 27.52 & 42.99 & 15.02 & 85.54 & 7.36 & 1.10 & 8.46 & 5.11 & 2.67 & 2.15 & 2.33 & 0.19 & 0.01 & 0.67 & 0.13 \\
\hline 25 & 52.71 & 16.57 & 3.31 & 72.59 & 14.46 & 1.20 & 15.7 & 9.9 & 4.82 & 4.52 & 0.00 & 0.30 & 0.30 & 3.61 & 2.41 \\
\hline 26 & 34.18 & 37.68 & 13.61 & 85.47 & 7.83 & 1.00 & 8.83 & 6.29 & 3.08 & 2.59 & 1.77 & 0.15 & 0.01 & 0.59 & 0.09 \\
\hline 27 & 42.49 & 30.09 & 11.15 & 83.73 & 8.73 & 1.04 & 9.77 & 6.71 & 4.38 & 3.90 & 1.21 & 0.12 & 0.02 & 0.66 & 0.11 \\
\hline 28 & nd & nd & nd & nd & nd & nd & nd & 13.8 & 0 & 0 & 0 & 0 & 0 & 6.15 & 0 \\
\hline
\end{tabular}


Table 5. Land use/land cover data for streams sampled in New York and South Carolina for U.S. Geological Survey mercury studies, 2005-09.-Continued

[Land use/land cover data are based on the National Land Cover Dataset for 2001 (NLCD01; Yang and others, 2002; Homer and others, 2004) for basins that were delineated using a geographic information system. More detailed wetland data, using a separate method of delineation, are included: APA wetland values for New York streams are from the Wetlands in the Greater Upper Hudson River Watershed dataset (New York State Adirondack Park Agency, 2007) and National Wetlands Inventory (NWI) wetland values for South Carolina streams are from the NWI dataset (U.S. Fish and Wildlife Service, 2010); nd, no data. Additional detailed land-use data are provided in appendixes 1 and 2. Primary sampling sites shown in bold]

\begin{tabular}{|c|c|c|c|c|c|c|c|c|c|c|c|c|c|c|c|}
\hline \multirow{3}{*}{$\begin{array}{c}\text { Map } \\
\text { number } \\
\text { (fig. 3) }\end{array}$} & \multicolumn{15}{|c|}{ Land use/land cover (percent of basin area) } \\
\hline & \multicolumn{4}{|c|}{ Forest } & \multicolumn{4}{|c|}{ Wetland } & \multirow[b]{2}{*}{$\begin{array}{c}\text { NLCD01 } \\
\text { Open } \\
\text { water }\end{array}$} & \multirow[b]{2}{*}{$\begin{array}{l}\text { NWI } \\
\text { Open } \\
\text { water }\end{array}$} & \multirow[b]{2}{*}{$\begin{array}{l}\text { NLCD01 } \\
\text { Shrubland }\end{array}$} & \multirow[b]{2}{*}{$\begin{array}{c}\text { NLCD01 } \\
\text { Herbaceous } \\
\text { upland }\end{array}$} & \multirow[b]{2}{*}{$\begin{array}{c}\text { NLCD01 } \\
\text { Agriculture }\end{array}$} & \multirow[b]{2}{*}{$\begin{array}{c}\text { NLCD01 } \\
\text { Developed* }\end{array}$} & \multirow[b]{2}{*}{$\begin{array}{c}\text { NLCD01 } \\
\text { Barren }\end{array}$} \\
\hline & $\begin{array}{c}\text { NLCD01 } \\
\text { Deciduous } \\
\text { forest }\end{array}$ & $\begin{array}{c}\text { NLCD01 } \\
\text { Evergreen } \\
\text { forest }\end{array}$ & $\begin{array}{c}\text { NLCD01 } \\
\text { Mixed } \\
\text { forest }\end{array}$ & $\begin{array}{c}\text { NLCD01 } \\
\text { Total } \\
\text { forest }\end{array}$ & $\begin{array}{l}\text { NLCD01 } \\
\text { Woody } \\
\text { wetland }\end{array}$ & $\begin{array}{c}\text { NLCD01 } \\
\text { Herbaceous } \\
\text { wetland }\end{array}$ & $\begin{array}{c}\text { NLCD01 } \\
\text { Total } \\
\text { wetland }\end{array}$ & $\begin{array}{c}\text { NWI } \\
\text { Total } \\
\text { wetland }\end{array}$ & & & & & & & \\
\hline \multicolumn{16}{|c|}{ South Carolina } \\
\hline 29 & 15.50 & 24.61 & 3.49 & 43.60 & 9.01 & 0.32 & 9.33 & nd & 1.09 & nd & 2.56 & 15.04 & 19.27 & 8.96 & 0.17 \\
\hline 30 & 15.40 & 31.78 & 6.37 & 53.54 & 6.94 & 0.29 & 7.24 & 5.06 & 0.99 & 1.15 & 0.45 & 19.63 & 12.87 & 5.24 & 0.04 \\
\hline 31 & 10.89 & 39.36 & 7.29 & 57.54 & 6.29 & 0.10 & 6.39 & 5.29 & 1.30 & 1.60 & 0.60 & 16.78 & 12.59 & 4.80 & 0.00 \\
\hline 32 & 13.08 & 30.10 & 6.39 & 49.58 & 7.96 & 0.23 & 8.19 & 6.35 & 1.04 & 1.24 & 0.49 & 21.07 & 14.87 & 4.73 & 0.00 \\
\hline 33 & 15.35 & 27.55 & 6.71 & 49.61 & 7.73 & 0.30 & 8.04 & 5.74 & 0.91 & 1.09 & 0.36 & 20.60 & 15.35 & 5.20 & 0.00 \\
\hline 34 & 10.30 & 36.19 & 6.75 & 53.25 & 6.93 & 0.09 & 7.01 & 6.06 & 1.21 & 1.39 & 0.61 & 18.87 & 14.72 & 4.50 & 0.00 \\
\hline 35 & 13.08 & 30.10 & 6.39 & 49.58 & 7.96 & 0.23 & 8.19 & 6.43 & 1.04 & 1.24 & 0.49 & 21.07 & 14.87 & 4.73 & 0.00 \\
\hline 36 & 11.33 & 26.62 & 4.55 & 42.50 & 10.05 & 0.41 & 10.45 & nd & 0.93 & nd & 8.26 & 12.65 & 17.84 & 7.06 & 0.31 \\
\hline 37 & 12.98 & 24.88 & 3.48 & 41.34 & 8.87 & 0.29 & 9.16 & nd & 1.21 & nd & 2.77 & 18.68 & 20.66 & 5.98 & 0.19 \\
\hline 38 & 8.34 & 26.09 & 4.53 & 38.96 & 10.18 & 0.40 & 10.58 & nd & 0.90 & nd & 10.3 & 11.34 & 21.34 & 6.25 & 0.30 \\
\hline 39 & 11.08 & 25.84 & 3.41 & 40.33 & 10.15 & 0.40 & 10.54 & nd & 1.13 & nd & 6.50 & 16.89 & 18.47 & 5.66 & 0.50 \\
\hline 40 & 3.11 & 26.31 & 2.10 & 31.52 & 15.41 & 0.57 & 15.98 & nd & 0.73 & nd & 14.4 & 4.80 & 25.54 & 6.94 & 0.06 \\
\hline 41 & 7.42 & 26.77 & 4.04 & 38.23 & 12.06 & 0.48 & 12.54 & nd & 0.88 & nd & 10.4 & 9.88 & 21.33 & 6.51 & 0.27 \\
\hline 42 & 10.10 & 25.38 & 3.23 & 38.72 & 10.27 & 0.39 & 10.67 & nd & 1.05 & nd & 6.91 & 15.75 & 20.35 & 6.20 & 0.36 \\
\hline 43 & 6.20 & 26.84 & 3.28 & 36.33 & 13.91 & 0.51 & 14.42 & nd & 0.88 & nd & 11.8 & 8.58 & 21.50 & 6.33 & 0.21 \\
\hline 44 & 3.29 & 23.37 & 0.27 & 26.93 & 17.97 & 0.44 & 18.42 & nd & 1.37 & nd & 16.3 & 5.12 & 21.64 & 10.11 & 0.09 \\
\hline 45 & 4.38 & 27.82 & 4.46 & 36.66 & 13.95 & 0.63 & 14.57 & nd & 0.50 & nd & 17.0 & 4.31 & 21.64 & 4.92 & 0.43 \\
\hline 46 & 2.95 & 29.00 & 1.09 & 33.03 & 19.00 & 0.70 & 19.70 & nd & 0.55 & nd & 10.0 & 2.94 & 28.84 & 4.89 & 0.09 \\
\hline 47 & 7.63 & 25.83 & 3.53 & 37.00 & 12.61 & 0.53 & 13.14 & nd & 0.81 & nd & 11.2 & 11.41 & 20.72 & 5.40 & 0.33 \\
\hline 48 & 5.60 & 25.51 & 2.74 & 33.85 & 15.22 & 0.54 & 15.77 & nd & 0.95 & nd & 12.4 & 7.95 & 20.98 & 7.95 & 0.18 \\
\hline 49 & 1.62 & 24.74 & 0.97 & 27.34 & 24.33 & 0.47 & 24.81 & nd & 0.34 & nd & 13.6 & 1.31 & 20.70 & 11.91 & 0.00 \\
\hline 50 & 5.78 & 25.16 & 2.57 & 33.51 & 16.91 & 0.69 & 17.60 & nd & 0.80 & nd & 10.7 & 8.53 & 23.46 & 5.14 & 0.25 \\
\hline 51 & 2.23 & 19.11 & 0.03 & 21.37 & 29.44 & 0.59 & 30.04 & nd & 0.82 & nd & 11.3 & 4.31 & 26.87 & 5.24 & 0.00 \\
\hline 52 & 3.73 & 22.92 & 1.98 & 28.63 & 20.32 & 0.62 & 20.94 & nd & 0.67 & nd & 10.9 & 5.31 & 26.10 & 7.19 & 0.30 \\
\hline 53 & 10.70 & 24.21 & 2.95 & 37.86 & 15.79 & 0.22 & 16.01 & nd & 0.62 & nd & 1.45 & 15.23 & 22.85 & 5.93 & 0.06 \\
\hline 54 & 9.50 & 23.61 & 2.75 & 35.86 & 17.90 & 0.24 & 18.13 & nd & 0.54 & nd & 2.06 & 13.01 & 24.28 & 5.98 & 0.14 \\
\hline
\end{tabular}

"In Riva-Murray and others (2011), urban and agricultural land cover/land use was combined under "developed." 
Table 6. Hydrologic data for primary stream sites sampled in New York and South Carolina for U.S. Geological Survey mercury studies for period of record and study period of 2005-09.

[ $\mathrm{ft}^{3} / \mathrm{s}$, cubic foot per second; WY, water year, the 12-month period, October 1-September 30. The water year is designated by the calendar year in which it ends; nd, no data; partial, only partial record available; values in range are minimum and maximum daily mean for period of record; data available at http://wdr.water.usgs.gov/]

\begin{tabular}{|c|c|c|c|c|c|c|c|}
\hline \multirow{2}{*}{$\begin{array}{c}\text { Map number } \\
\text { (figs. 3, 10) }\end{array}$} & \multirow{2}{*}{$\begin{array}{c}\text { Period of } \\
\text { record (WY) }\end{array}$} & \multicolumn{6}{|c|}{ Mean annual streamflow $\left(\mathrm{ft}^{3} / \mathrm{s}\right)$} \\
\hline & & Period of record & WY 2005 & WY 2006 & WY 2007 & WY 2008 & WY 2009 \\
\hline \multicolumn{8}{|c|}{ New York } \\
\hline 12 & 2007-09 & $58.8(5.2-508)$ & nd & nd & partial & 61.8 & 55.9 \\
\hline 27 & 1926-2010 & $411(11-6,780)$ & 413 & 604 & 532 & 603 & 498 \\
\hline \multicolumn{8}{|c|}{ South Carolina } \\
\hline 30 & 1996-2010 & $16.4(1.4-248)$ & 18.2 & 14.2 & 12.5 & 9.94 & 12.7 \\
\hline 35 & 2007-09 & $22.8(2.6-163)$ & nd & nd & partial & 19.2 & 26.4 \\
\hline 54 & 1939-2010 & $2,478(150-24,100)$ & 1,765 & 1,193 & 1,306 & 929 & 1,579 \\
\hline
\end{tabular}

Table 7. Mean annual water temperature and range for primary stream sites sampled in New York and South Carolina for U.S. Geological Survey mercury studies, 2005-09.

$\left[{ }^{\circ} \mathrm{C}\right.$, degrees Celsius; $\mathrm{CY}$, calendar year; nd, no data $]$

\begin{tabular}{|c|c|c|c|c|c|c|c|}
\hline \multirow{2}{*}{$\begin{array}{c}\text { Map number } \\
\text { (figs. } 3,10 \text { ) }\end{array}$} & \multirow{2}{*}{$\begin{array}{l}\text { Period of } \\
\text { record (CY) }\end{array}$} & \multicolumn{6}{|c|}{ Mean annual water temperature $\left({ }^{\circ} \mathrm{C}\right)$} \\
\hline & & Period of record & CY 2005 & CY 2006 & CY 2007 & CY 2008 & CY 2009 \\
\hline \multicolumn{8}{|c|}{ New York } \\
\hline 7 & $2007-09$ & $12.7(-0.1-23.2)$ & nd & nd & 10.3 & 12.7 & 15.1 \\
\hline 12 & $2007-09$ & $10.4(-0.1-23.8)$ & nd & nd & 11.0 & 10.1 & 10.2 \\
\hline 27 & 2005-09 & $12.1(0.0-23.0)$ & 9.6 & 9.0 & 15.5 & 11.7 & 14.9 \\
\hline \multicolumn{8}{|c|}{ South Carolina } \\
\hline 30 & 2005-09 & $18.0(5.2-25.9)$ & 17.8 & 19.1 & 17.4 & 16.4 & 19.5 \\
\hline 35 & 2007-09 & $17.5(3.0-25.7)$ & nd & nd & 18.7 & 17.8 & 15.8 \\
\hline 54 & $2005-09$ & $21.1(7.1-28.9)$ & 18.9 & 18.9 & 19.8 & 26.9 & 21.1 \\
\hline
\end{tabular}


The climate of this area in New York is temperate continental with relatively long, cold winters and a lengthy dormant season. Summers are cool and wet, and the growing season is fairly short with a frost-free period of less than 150 days (National Climatic Data Center, 2011b). Cold, dry air masses from the northern continental interior and warm, humid air masses from south and southwest drive most of the climate characteristics. Cool, damp air masses from the North Atlantic Ocean during storms can also affect the inland climate of New York. Moisture for precipitation originates generally from the Gulf of Mexico and the Atlantic Ocean; however, Lakes Erie and Ontario contribute to the generally abundant snowfall of the study area (Pack, 1960).

After reconnaissance sampling in 2006, sampling efforts focused in the Fishing Brook Subbasin, which is defined here as that portion upstream of the County Line Flow outlet (Site 12) as well as the Hudson River at Newcomb (Site 27). The following sections provide additional detail on the environmental settings of these stream sites.

\section{Upper Hudson River Basin}

The Hudson River near Newcomb (Site 27), in Essex County, drains about $493 \mathrm{~km}^{2}$ and lies at an elevation of $468 \mathrm{~m}$ above sea level (table 1). This site and others in the Upper Hudson River Basin are in the mountainous Adirondack region, which also is part of the Northeastern Highlands ecoregion (Omernik, 1987; U.S. Environmental Protection Agency, 2005). The Upper Hudson River Basin is entirely in the Adirondack Park, and is mostly undeveloped, with large portions of protected wilderness (fig. 2, Jenkins, 2004). Land use/land cover (fig. 3, table 5) is primarily forested, predominantly deciduous trees (sugar maple [Acer saccharum], yellow birch [Betula alleghaniensis], and American beech [Fagus grandifolia]) with evergreen trees (red spruce [Picea rubens] and balsam fir [Abies balsamea]) dominant at elevations above $1,000 \mathrm{~m}$ and adjacent to surface waters and wetlands (State University of New York - College of Environmental Science and Forestry, 2011). Part of the forested

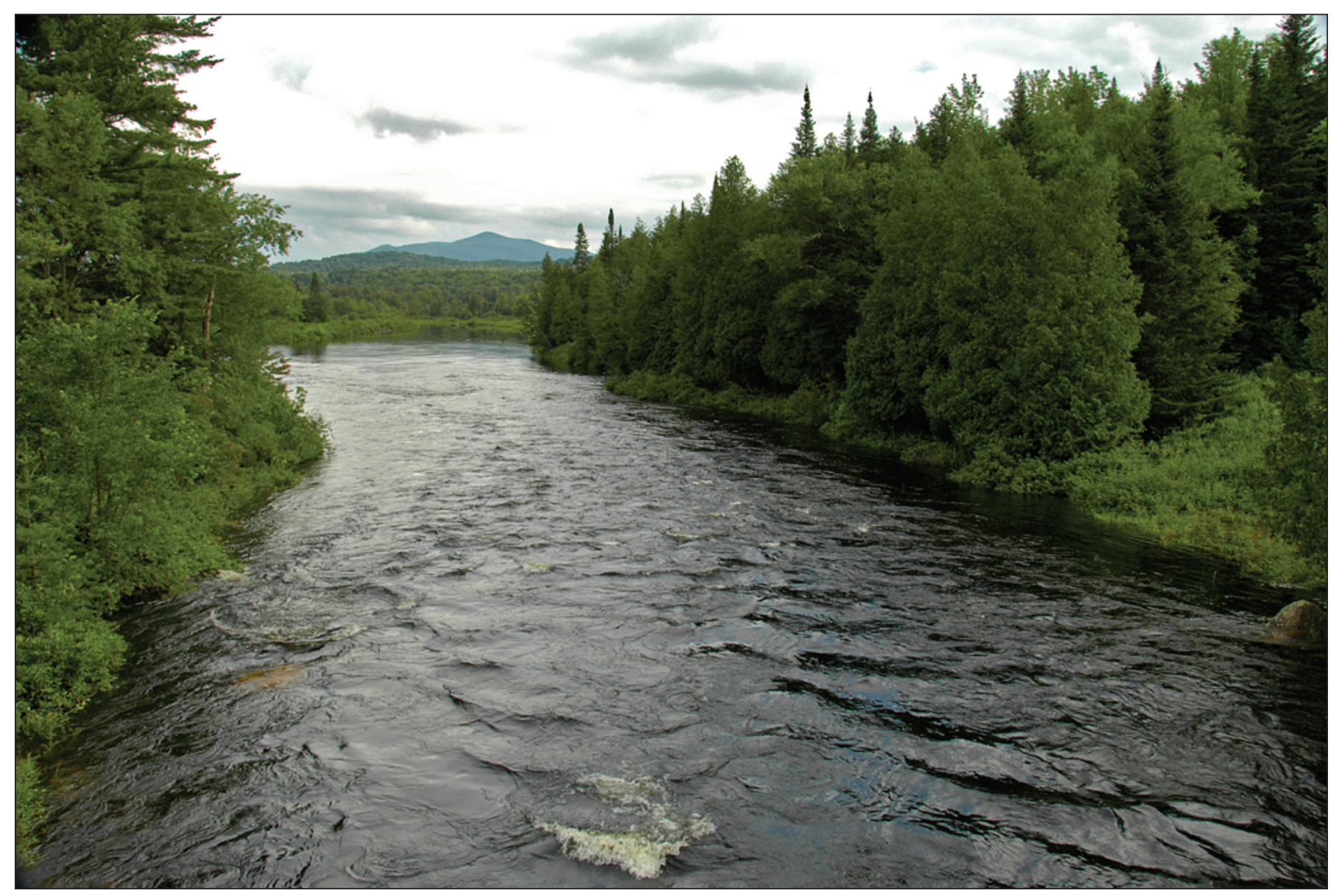

Figure 2. Hudson River near Newcomb, New York (Site 27 in table 1 and figure 3) (summer). Photograph by Dennis A. Wentz, U.S. Geological Survey. 


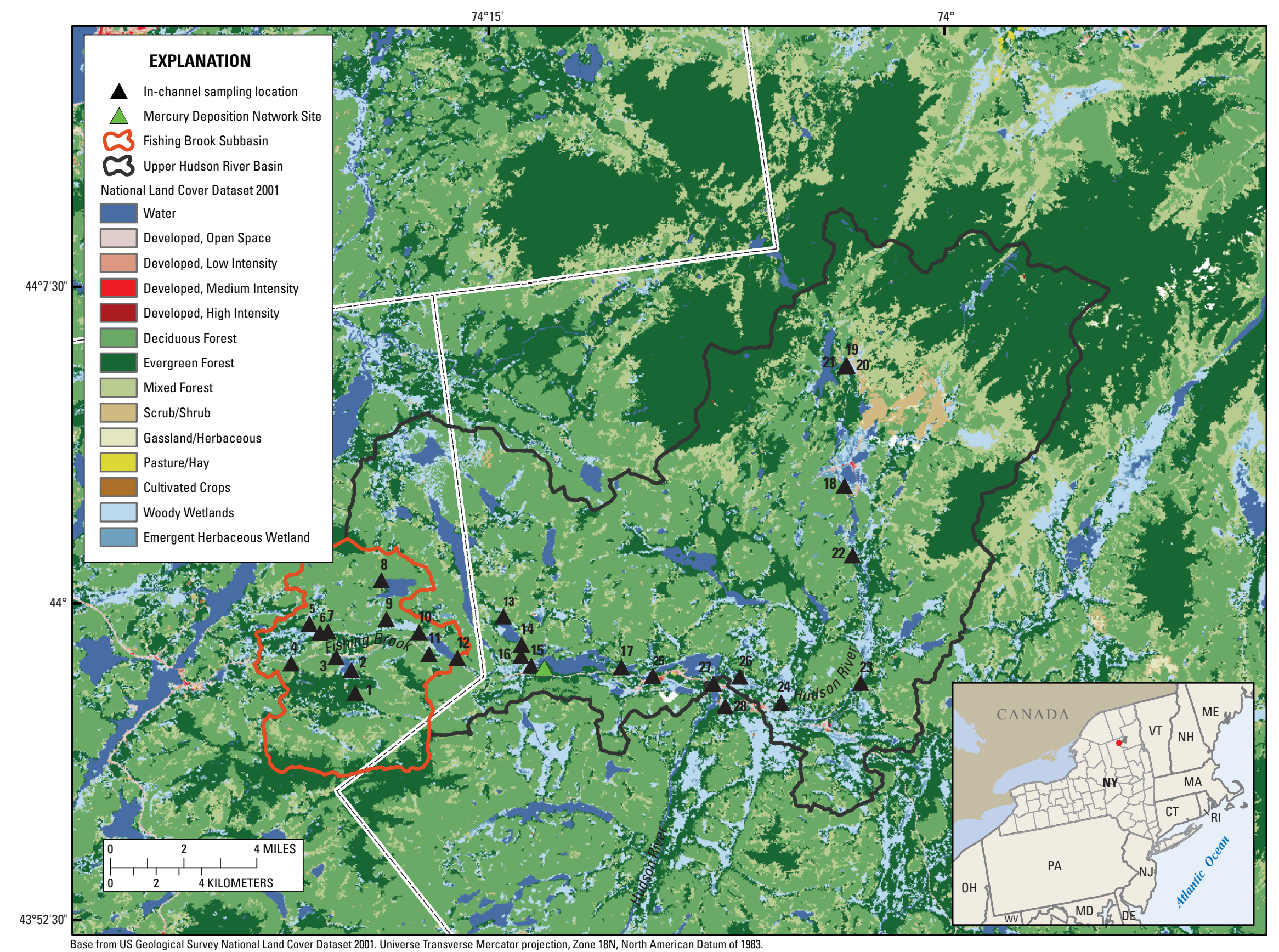

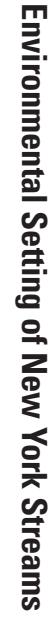

Figure 3. Land use/land cover of Upper Hudson River Basin near Newcomb, New York, with nested outline of Fishing Brook Subbasin in headwaters. Map numbers refer to sites listed in table 1. 
land is used for silviculture. There is a relatively high amount (about 10 percent) of wetlands, and woody wetland (including forest and shrub/scrub) is the dominant wetland type (fig. 3, table 5). Lakes, ponds, and low-head dams are prevalent. A small $\left(5 \mathrm{~km}^{2}\right)$ northeastern section of the basin was the site of mining for iron during 1827-57 and titanium during 1940-89 (New York State Adirondack Park Agency, 2011); this area now appears as shrub-scrub on land use/land cover maps (fig. 3). The river flows south from the Adirondack region, eventually reaching the City of New York metropolitan area and New York Harbor before flowing into the Atlantic Ocean.

Data for mean air temperatures, precipitation, and mean total $\mathrm{Hg}$ in wet atmospheric deposition for the Hudson River at Newcomb, N.Y. (Site 27), are assumed to be similar to those measured or derived for the headwaters site at Fishing Brook (County Line Flow outlet) near Newcomb, N.Y. (Site 12) based on data from nearby NCDC and NADP-MDN sites (table 4). Mean annual streamflow for the period of record (water years (WYs) 1979-2010) at Site 27 was 411 cubic feet per second $\left(\mathrm{ft}^{3} / \mathrm{s}\right)$; mean annual streamflow ranged from $413 \mathrm{ft}^{3} / \mathrm{s}$ in 2005 to $604 \mathrm{ft}^{3} / \mathrm{s}$ in 2006 (table 6). Daily mean streamflow was weighted by area to compute estimated runoff (millimeters per day) for a common metric of comparison between the New York and South Carolina study areas. During the period of study, mean water temperatures for the Hudson River near Newcomb, N.Y. (Site 27), ranged from 0 to $23.0^{\circ} \mathrm{C}$ with a mean annual water temperature of $12.1^{\circ} \mathrm{C}$ (table 7$)$.

\section{Fishing Brook Subbasin}

Fishing Brook lies in a small western subbasin of the Upper Hudson River Basin and is in Hamilton and Essex Counties near Newcomb, N.Y. (figs. 3 and 4, table 1). The most-downstream site studied within this subbasin, Fishing Brook near Newcomb (Site 12), drains $65.6 \mathrm{~km}^{2}$ and is at the downstream end of County Line Flow, an impoundment (fig. 5). The study area is upstream of Rich Lake and is just west of the $60-\mathrm{km}^{2}$ Huntington Wildlife Forest (http://www.esf. edu/aec/facilities/hwf.htm) in the central Adirondack Mountains. Site 12 is about $4 \mathrm{~km}$ west of the NADP-MDN site NY20, which is at the Huntington Wildlife Forest. Land use/ land cover for the Fishing Brook Subbasin upstream of Site 12

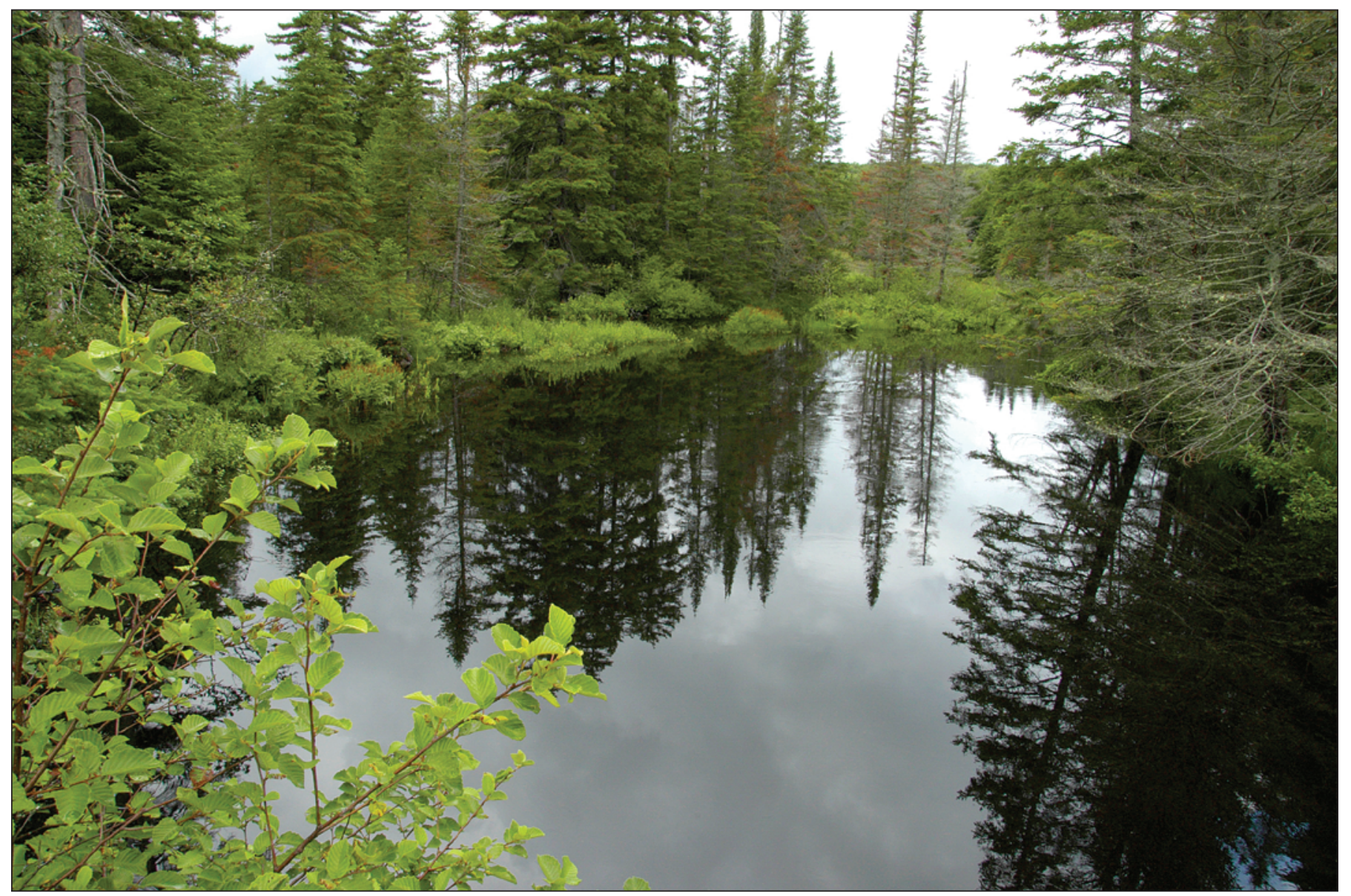

Figure 4. Fishing Brook above County Line Flow near Long Lake, New York (Site 10 in table 1 and figure 3) (summer). Photograph by Dennis A. Wentz, U.S. Geological Survey. 
consists primarily ( 86 percent) of upland forests, with slightly over one-half of the land area as deciduous forest (dominated by northern hardwoods such as sugar maple, American beech, and yellow birch), about one-quarter of the land area as evergreen forest (dominated by red spruce and balsam fir), and the remaining forest area with a mix of evergreen and deciduous trees (figs. 6 and 7, table 5); logging is common. Wetland area is about 9 percent and is largely comprised of a combination of woody vegetation (evergreens, such as spruce, are dominant but with areas of deciduous shrubs, such as speckled alder, Alnus incana) and emergent herbaceous vegetation.

During the study period, the mean winter-air temperature was $-7.9^{\circ} \mathrm{C}$, and the mean summer-air temperature was $17.6^{\circ} \mathrm{C}$ at the primary Fishing Brook site (Site 12; table 4). Annual precipitation at the site during 2005-2009 averaged $1,269 \mathrm{~mm} / \mathrm{yr}$, partly as snow. Based on 30-year averages (1971-2000) for the NCDC station at Newcomb, N.Y., conditions were slightly warmer and wetter than average during 2007-09. For the NCDC station data, about 28 percent of the 30 -year average annual precipitation $(1,077 \mathrm{~mm})$ was snowfall, based on 30-year average precipitation amounts for the winter months (December through March).

Three NADP monitoring sites are located near the Fishing Brook Subbasin, including National Trends Network (NTN) site NY20 (table 3). Major ions and solutes are sampled on a weekly basis at these NTN sites. Site NY20 also has provided data on $\mathrm{Hg}$ in precipitation since 1999 as part of the NADP-MDN; it is located at the Huntington Wildlife Forest. During 2005-09, mean total Hg in wet atmospheric deposition was $6.69 \mu \mathrm{g} / \mathrm{m}^{2} / \mathrm{yr}$ based on computed values when PRISM-modeled precipitation values were combined with $\mathrm{Hg}$ values from NADP-MDN (table 4).

Mean annual streamflow for Fishing Brook (County Line Flow outlet) near Newcomb, N.Y. (Site 12) was $58.8 \mathrm{ft}^{3} / \mathrm{s}$ (WYs 2008 and 2009) and ranged from $55.9 \mathrm{ft}^{3} / \mathrm{s}$ in WY 2009 to $61.8 \mathrm{ft}^{3} / \mathrm{s}$ in WY 2008; only a partial streamflow record existed for WY 2007 at this site, so no annual statistics were computed for that year (table 6). Water temperatures ranged from -0.1 to $23.8^{\circ} \mathrm{C}$, with a mean annual water temperature of $10.4^{\circ} \mathrm{C}$ during $2007-2009$ (table 7).

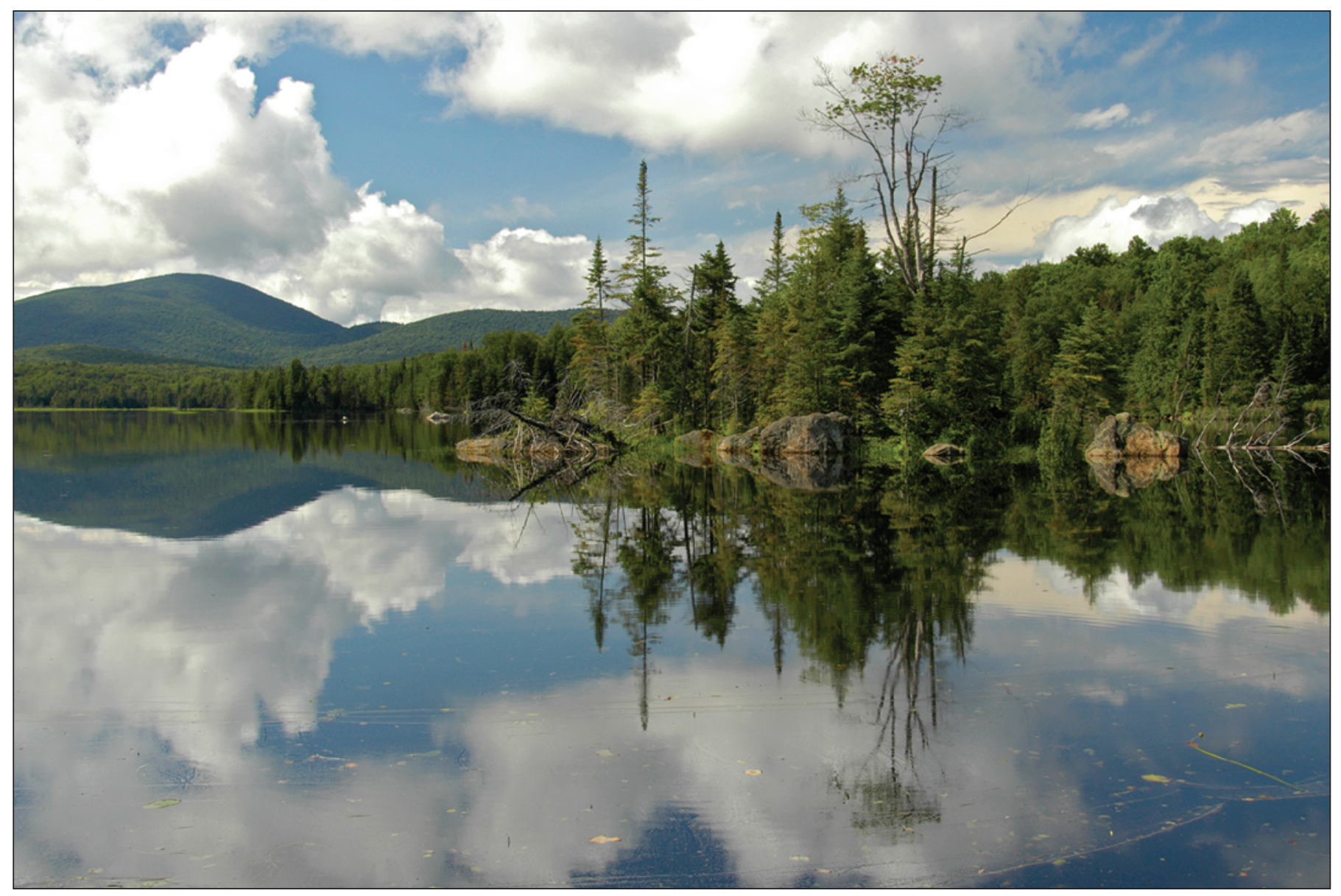

Figure 5. Fishing Brook (County Line Flow outlet) near Newcomb, New York (Site 12 in table 1 and figure 3) (summer). Photograph by Dennis A. Wentz, U.S. Geological Survey. 


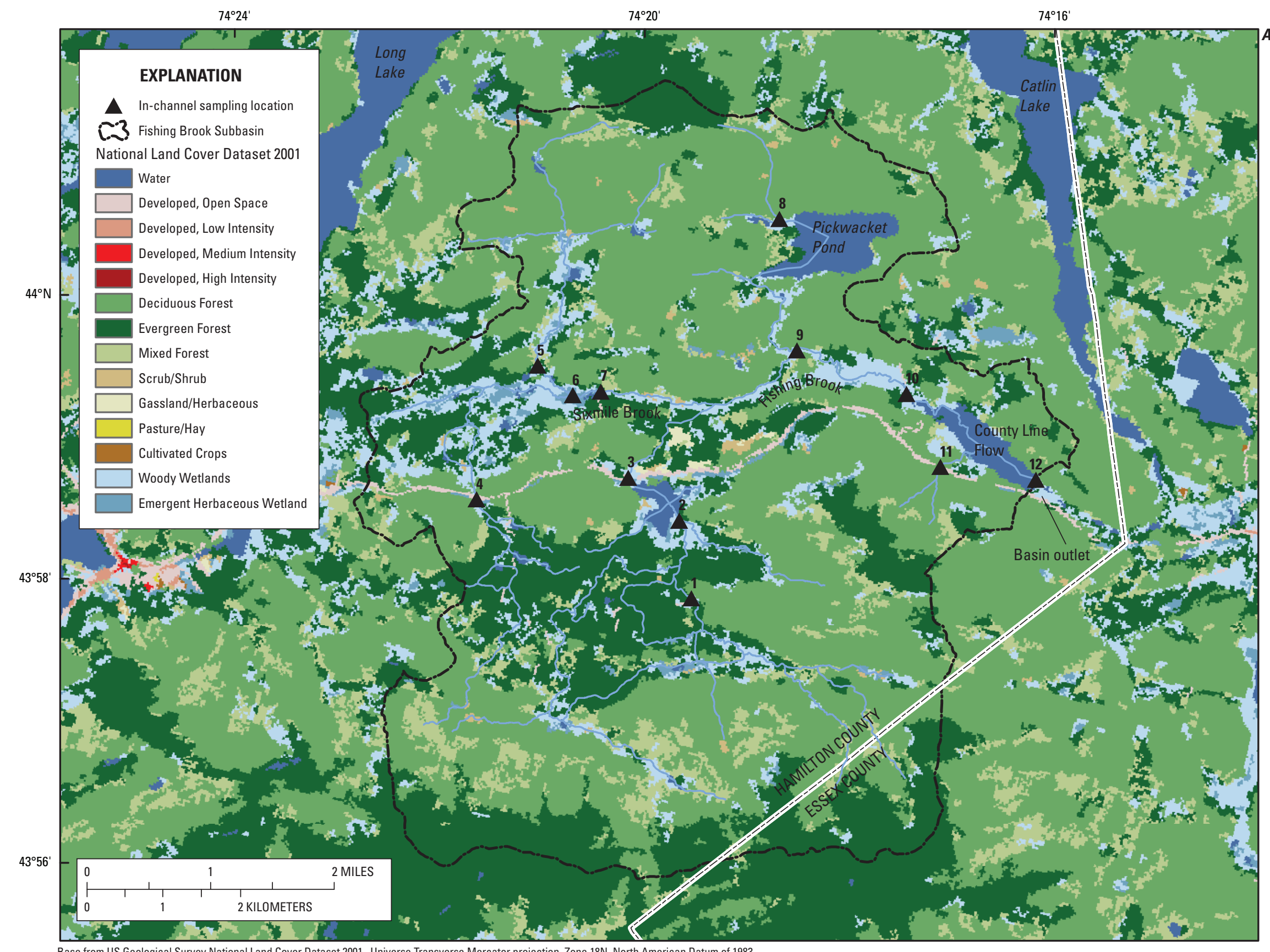

Figure 6A. Detailed land use/land cover and wetland cover for Fishing Brook Subbasin, New York: land use/land cover, based on National Land Cover Dataset for 2001 (NLCD01). 


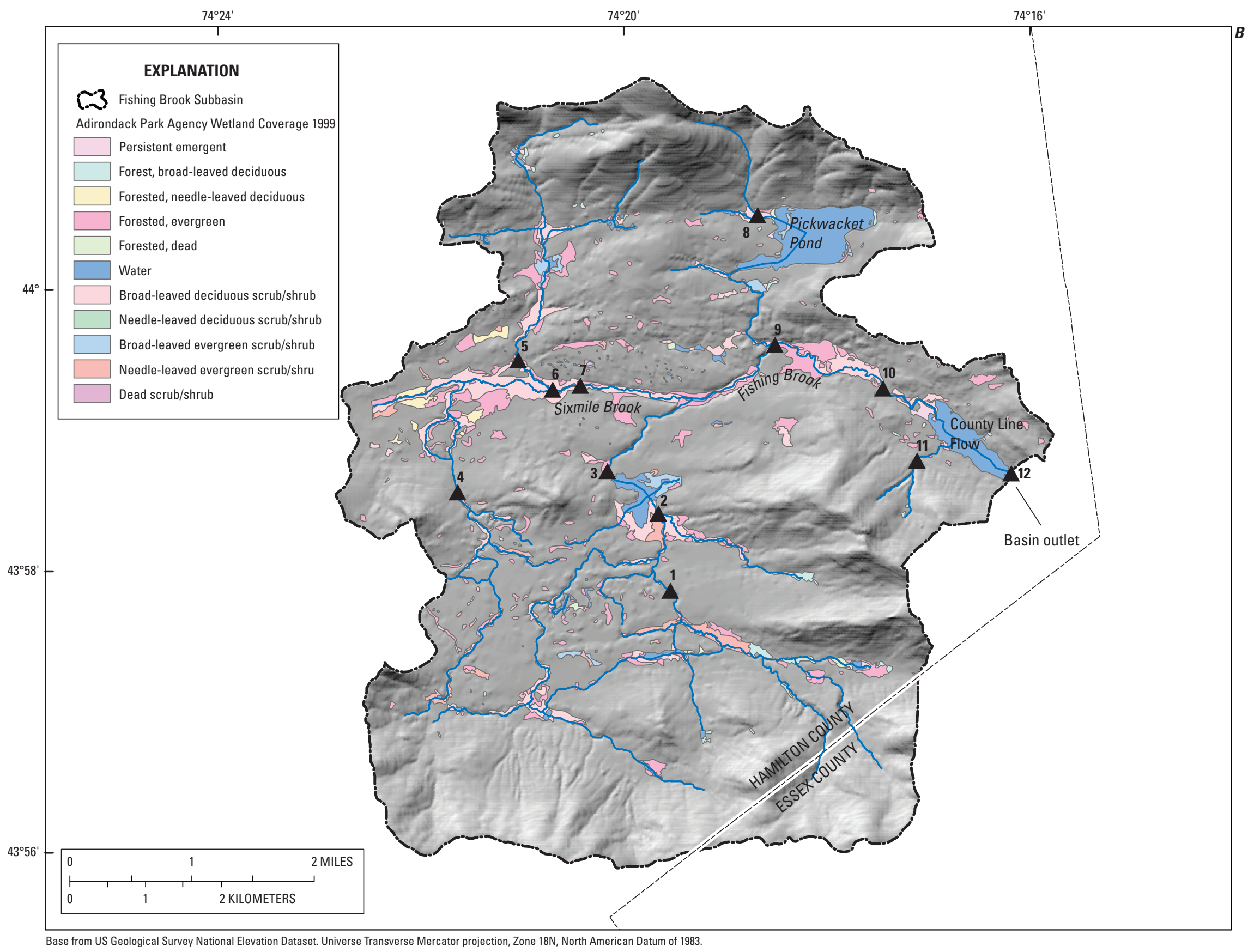

Figure 6B. Detailed land use/land cover and wetland cover for Fishing Brook Subbasin, New York: wetland cover, based on New York State Adirondack Park Agency data. Map numbers refer to sites listed in table 1. 


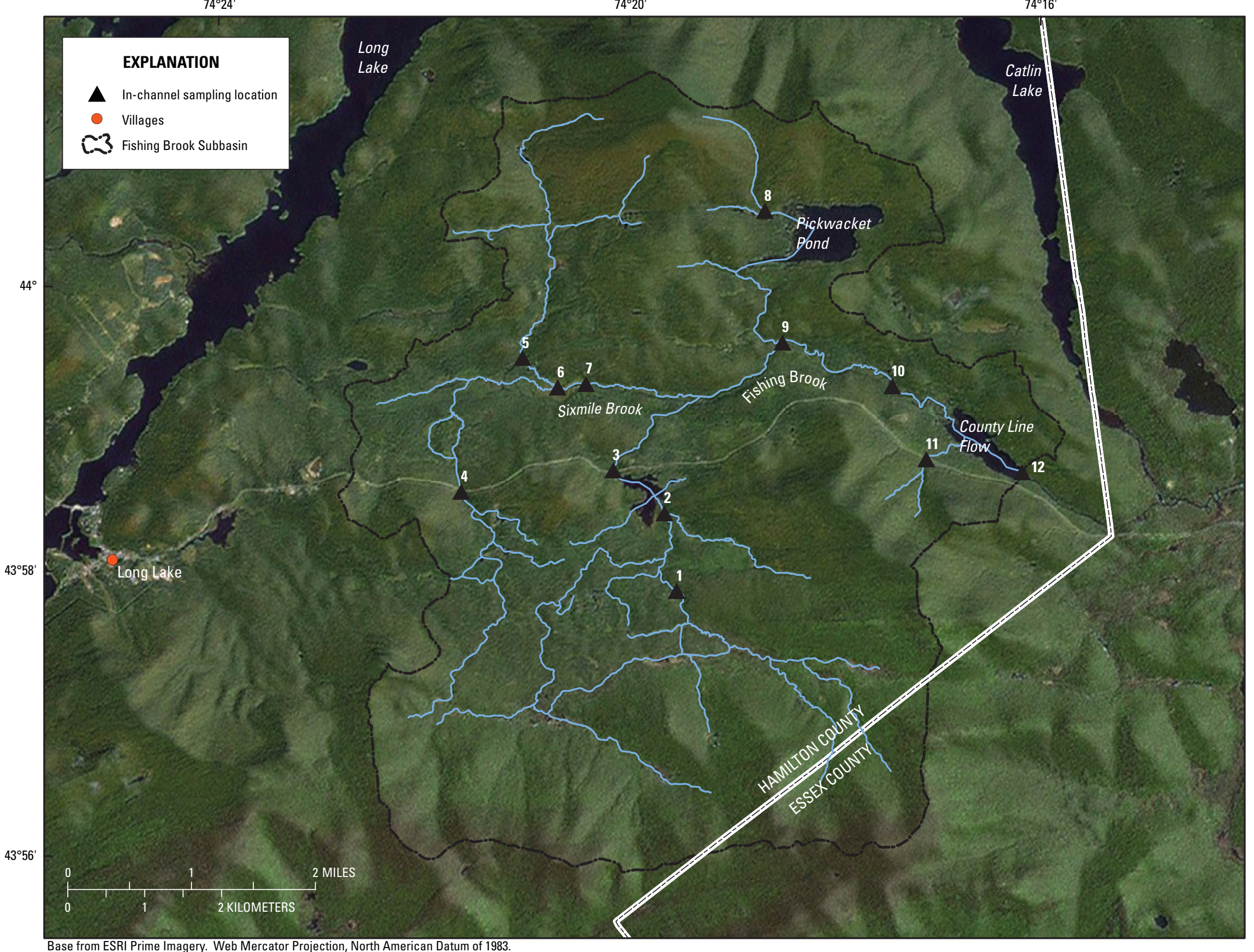

Figure 7. Fishing Brook Subbasin, New York, showing sampling locations. Map numbers refer to sites listed in table 1. 
The major tributary to Fishing Brook-Sixmile Brookdrains a basin of about $18 \mathrm{~km}^{2}$ and joins Fishing Brook between Sites 3 and 10 (figs. 3 and 8A). Based on NLCD01 data, wetland percentages for downstream reaches of Sixmile Brook (Sites 6 and 7) are about 14 percent, slightly higher than for downstream reaches of Fishing Brook Subbasin near Site 12 (table 5). The Pickwacket Pond outlet (Site 9) is at $505 \mathrm{~m}$ elevation and, although it drains a small basin of only $8.4 \mathrm{~km}^{2}$, more than 11 percent of the basin area is open water and about 5.2 percent is wetland (figs. 3 and $8 B$, Pickwacket Pond Inlet). Its confluence with Fishing Brook is downstream from that of Sixmile Brook. Wetlands of the Sixmile Brook and Pickwacket Pond Subbasins are primarily wooded (evergreen forest and deciduous shrub/scrub dominant (table 5). County Line Flow, Sixmile wetland (formerly a flow), and Fishing Brook Flow were all a result of constructed features for transporting logs during historical logging activity (Jenkins, 2004).
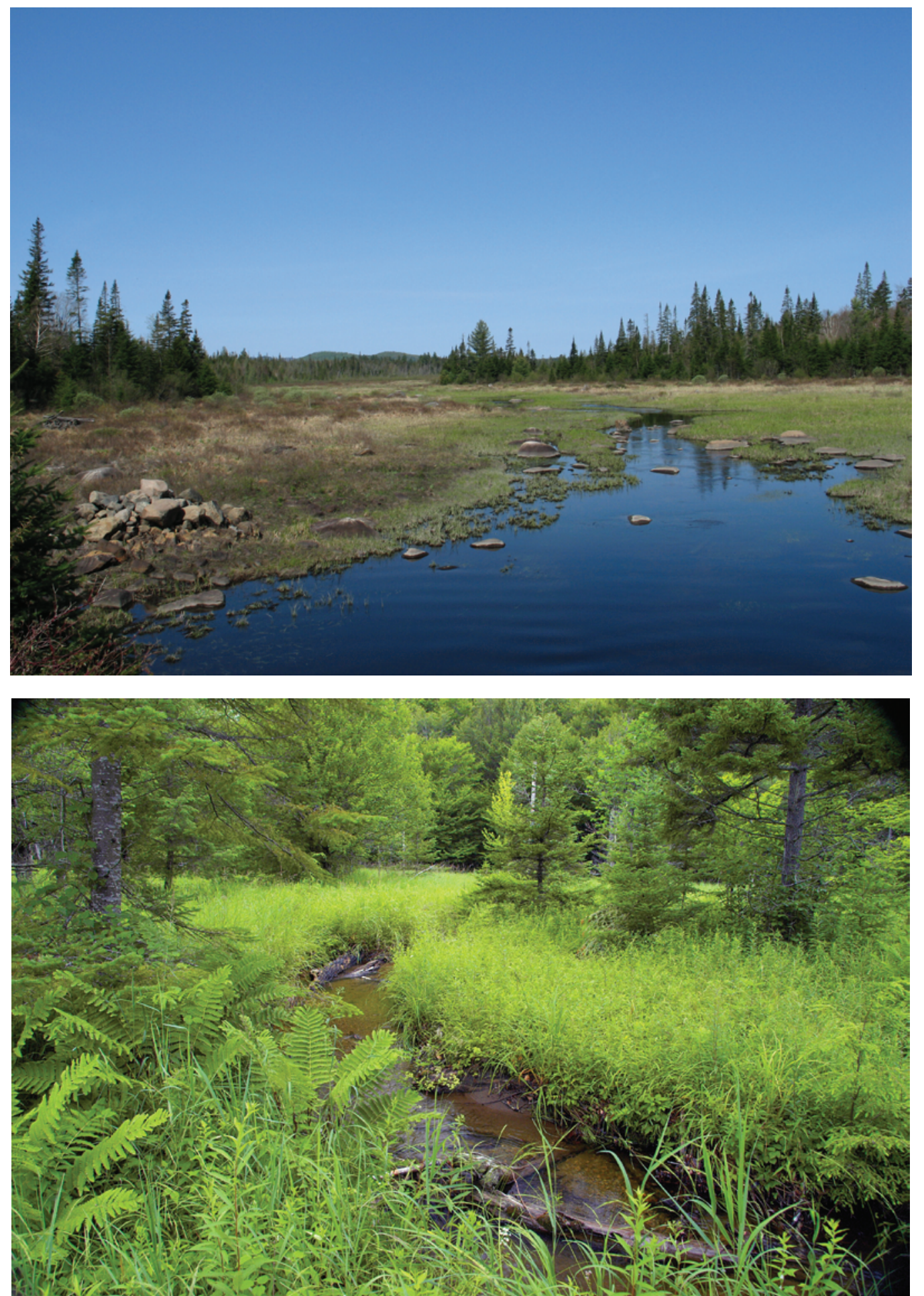

Figure 8. (A) Sixmile Brook near Long Lake, New York (Site 7) (summer), major tributary to Fishing Brook and (B) Pickwacket Pond Inlet near Long Lake, N.Y. (Site 9) (summer). Photographs by Douglas A. Burns and Dennis A. Wentz, respectively, U.S. Geological Survey. 


\section{Environmental Setting of South Carolina Streams}

The South Carolina streams sampled for the 2005-09 NAWQA Hg studies are in the Edisto River Basin, which is part of the larger Santee River Basin (fig. 1, table 1). Reconnaissance sampling (2005-06) was conducted throughout the Edisto River Basin, and intensive sampling (2007-09) focused in the McTier Creek Subbasin. Elevations in the Edisto study basin range from $8.5 \mathrm{~m}$ at the most-downstream site on the Edisto River near Givhans (Site 54) to $207 \mathrm{~m}$ near the town of Ward, S.C. (appendix 2). The McTier Creek sites range in elevation from 96 to $106 \mathrm{~m}$. In contrast with the New York study area, the South Carolina streams are characterized by generally low slopes; the median basin slope is about 5.5 percent.

Land use/land cover for the sample sites ranges from about 21 to 58 percent forested land cover (dominated by evergreens), and about 1 to 21 percent herbaceous upland (table 5, appendix 2). Wetland area (NLCD01) ranges from 6 to 8 percent in the McTier Creek Subbasin (Site 35), up to 30 percent at North Fork Edisto River near Branchville, S.C. (Site 51), and to about 18 percent at the most-downstream site on the Edisto River near Givhans (Site 54). The amount of open water (lakes and ponds, both natural and man-made) is less than 1 or 2 percent and varies little among the subbasins studied in the Edisto River Basin. About 13 to 29 percent of the land in some subbasins is agricultural (row crops of corn, soybeans, and cotton; pasture for hay and cattle), and 4 to 12 percent of the land is developed (urban).

The climate of this area in South Carolina is sub-tropical with relatively mild winters and distinct wet and dry seasons. The wet and dry seasons result in seasonally fluctuating water levels in riparian pools, wetlands, and streams of the area (Bradley and others, 2011). However, it should be noted that a drought of historical significance occurred in South Carolina in 2007 (Feaster and others, 2010). With a frost-free period of about 210 days, the growing season in South Carolina is long relative to the growing season in New York (National Climatic Data Center, 2011b). Warm, humid air masses from the Atlantic Ocean drive most of the climate characteristics. In addition, the Appalachian mountain range has an important influence on the climate because it serves as a barrier to many cold air masses from the northwest, moderating temperatures and affecting the prevailing wind direction. Prevailing winds are generally from the southwest and south in the spring/summer and from the northeast and southwest during the fall/winter (South Carolina State Climatology Office, 2011).

After reconnaissance sampling in 2006, sampling efforts focused in the McTier Creek Subbasin, defined here as that portion upstream of New Holland (Site 35) and on the main stem Edisto River near Givhans (Site 54; biological sampling for the Edisto River was done upstream of Givhans near Cottageville, Site 53). The following sections provide additional detail on the environmental settings of these stream sites.

\section{Edisto River Basin}

The Edisto River is one of the longest free-flowing (no dams or levees) blackwater rivers in the United States. It flows over $300 \mathrm{~km}$ from its headwaters to its mouth at the Atlantic Ocean and lies within the Southeastern Plains and Middle Atlantic Coastal Plain Level III ecoregions (Omernik, 1987; Griffith and others, 2002; U.S. Environmental Protection Agency, 2005). The Edisto is called a "blackwater" stream because of its clear and dark, amber-colored water resulting from plant tannins leaching out of abundant cypress forests or wetlands (fig. 9). Although the Edisto River Basin lies mainly within the Coastal Plain physiographic province of South Carolina, the uppermost portion of the basin lies in the Piedmont physiographic province.

The Edisto River has a North Fork and a South Fork, and the McTier Creek Basin is the headwaters tributary to the South Fork of the Edisto River. The Edisto River near Givhans (Site 54), in Dorchester County, is downstream of the confluence of the two river forks. At this point, it drains $7,071 \mathrm{~km}^{2}$ and lies at an elevation of only $8.5 \mathrm{~m}$ above sea level (table 1 ). Land use/land cover (table 5, fig. 10) for Site 54 is about 36 percent forested, mostly as evergreen forest that is used partly for silviculture in the McTier Creek Subbasin, and about 18 percent wetland (based on NLCD01), mostly as woody wetland dominated by bald cypress (Taxodium distichum) and swamp tupelo (Nyssa biflora). Four Holes Swamp (Site 52) is a major tributary of the Edisto River.

Data for mean air temperatures, precipitation, and mean total $\mathrm{Hg}$ in wet atmospheric deposition were not measured directly but are assumed to be similar to those measured or derived for the headwaters site at McTier Creek near New Holland (Site 35) using data from the nearby NCDC and NADP-MDN sites (table 4).

The hydrology of the Edisto River Basin is characterized by groundwater-flood events, which tend to promote upward transport of $\mathrm{MeHg}$ from wetland and floodplain sediment to the water column, thereby enhancing the bioavailability of $\mathrm{Hg}$ to stream organisms (Bradley and others, 2009, 2010; Feaster and others, 2010). Mean annual streamflow for the period of record (WYs 1939-2010) at the Edisto River near Givhans (Site 54) was 2,478 ft $3 / \mathrm{s}$; mean annual streamflow during water years 2005-2007 ranged from a low of $929 \mathrm{ft}^{3} / \mathrm{s}$ in WY 2007 to a high of 1,765 $\mathrm{ft}^{3} / \mathrm{s}$ in WY 2005 (table 6). During the study period, mean water temperatures for Site 54 ranged from 7.1 to $28.9^{\circ} \mathrm{C}$, with an annual mean of $21.1^{\circ} \mathrm{C}$ (table 7 ). 


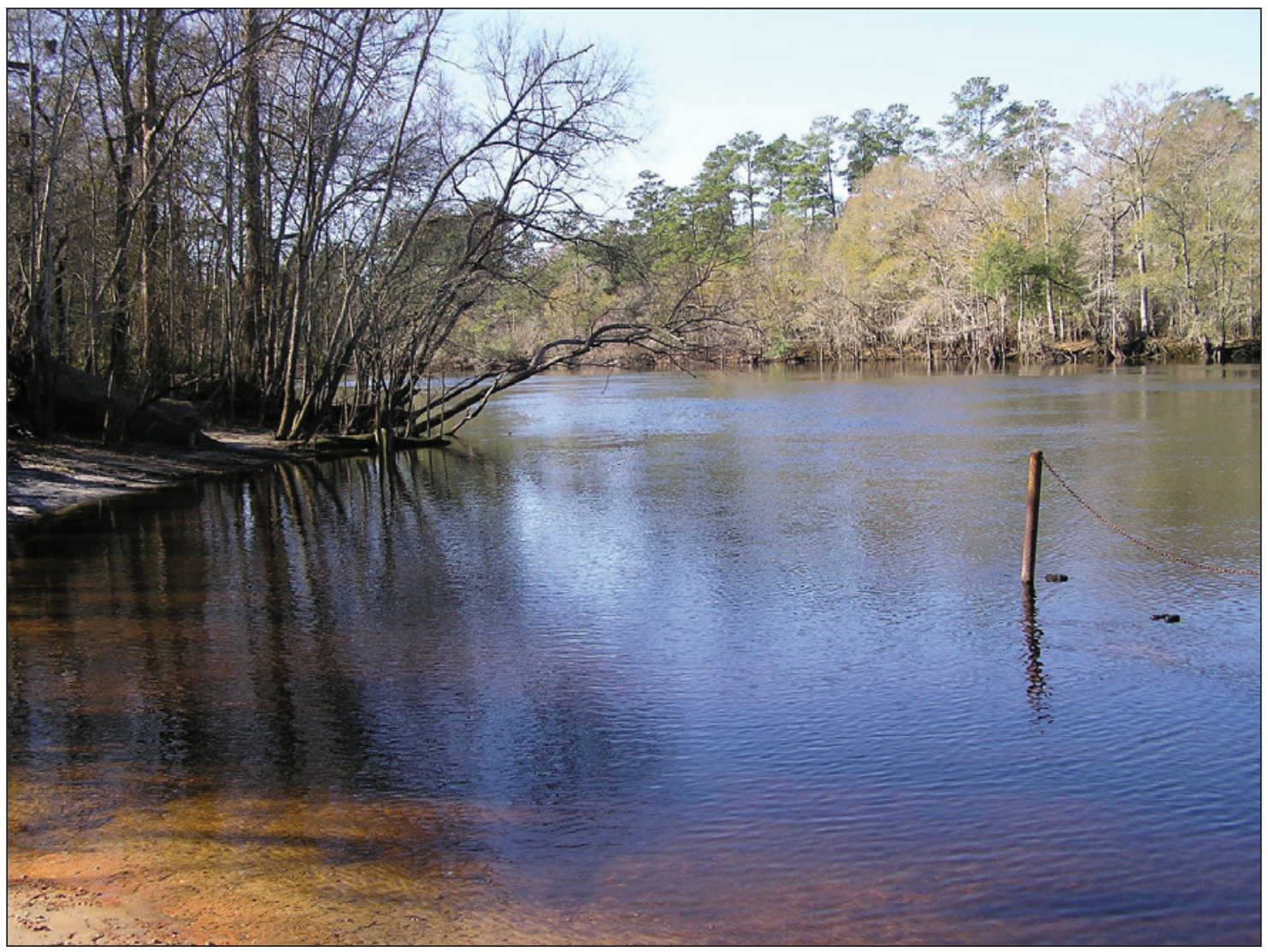

Figure 9. Photograph of Edisto River Basin near Givhans, South Carolina (Site 54 in table 1 and figure 10) (winter). Photograph by Celeste A. Journey, U.S. Geological Survey. 


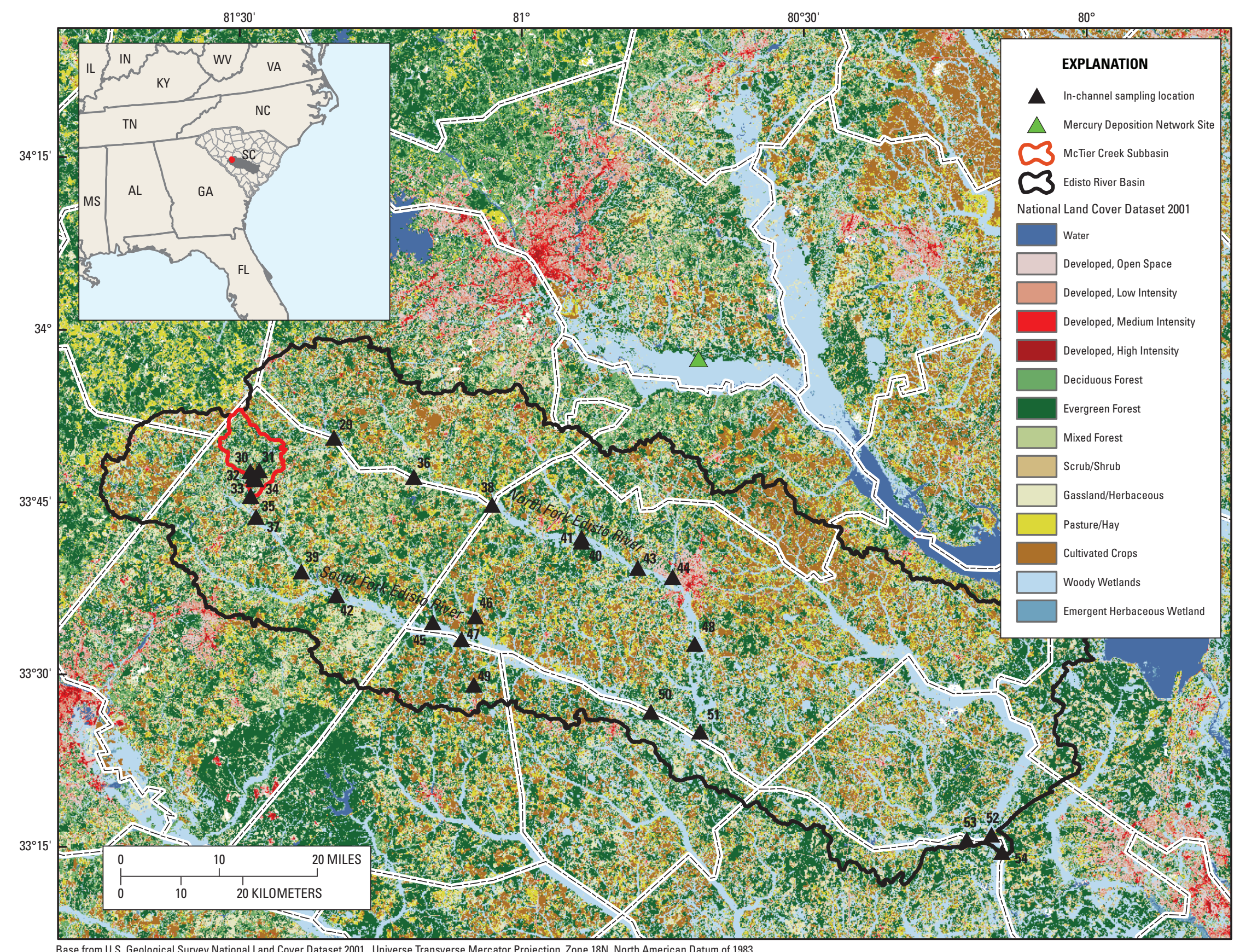

Figure 10. Map of detailed land use/land cover for Edisto River Basin near Givhans, South Carolina, with nested outline of McTier Creek Subbasin. Map numbers refer to sites listed in table 1. 


\section{McTier Creek Subbasin}

McTier Creek lies in a small subbasin of the Edisto River Basin and is in Aiken County, S.C. (figs. 3 and 11, table 1). The most-downstream site studied drains $79.4 \mathrm{~km}^{2}$ and is near New Holland (Site 35), close to its confluence with the South Fork of the Edisto River. Site 35 is about $77 \mathrm{~km}$ from NADP-MDN site SC19. The creek lies within the Sand Hills area of the Coastal Plain (Griffith and others, 2002). The upper reaches of the McTier Creek Subbasin near Monetta (Site 30) are near the Fall Line, the boundary between the Piedmont and Southeastern Plains ecoregions (also Piedmont and Coastal Plain Physiographic Provinces), and the stream transitions from characteristics similar to Piedmont streams (high gradient with rock substrate) in the headwaters to characteristics similar to Coastal Plain streams (low gradient with sandy substrate) (Feaster and others, 2010; Omernik, 1987; U.S. Environmental Protection Agency, 2005). The lower reaches of the McTier Creek Subbasin near New Holland (Site 35) exhibit lowland characteristics of the Southeastern Plains ecoregion (Feaster and others, 2010; Omernik, 1987; U.S. Environmental Protection Agency, 2005). Land use/land cover (NLCD01) for the McTier Creek drainage is about 50 percent upland forests, mostly evergreens such as loblolly pine (Pinus taeda, as silviculture) or longleaf pine (Pinus palustris) with some deciduous trees (turkey oak [Quercus cerris]), and 21 percent herbaceous upland (figs. 12 and 13, table 5). Agricultural land accounts for about 15 percent of the basin area. Wetland makes up about 7 percent of the total basin area at Site 30 and about 8 percent at Site 35, which is slightly less than that for Fishing Brook near Newcomb, N.Y. (Site 12), with about 9 percent. Similar to the NY study basins, wetlands in the South Carolina basins are dominated by woody vegetation. Woody vegetation in the McTier Creek Subbasin is dominated by broad-leaved deciduous trees, such as red maple (Acer rubrum), mixed oaks (Quercus spp.), holly (Ilex opaca and I. vomitoria), tulip poplar (Liriodendron tulipifera), sweetgum (Liquidambar styraciflua), black or sour gum (Nyssa sylvatica), and swamp tupelo (Nyssa biflora).

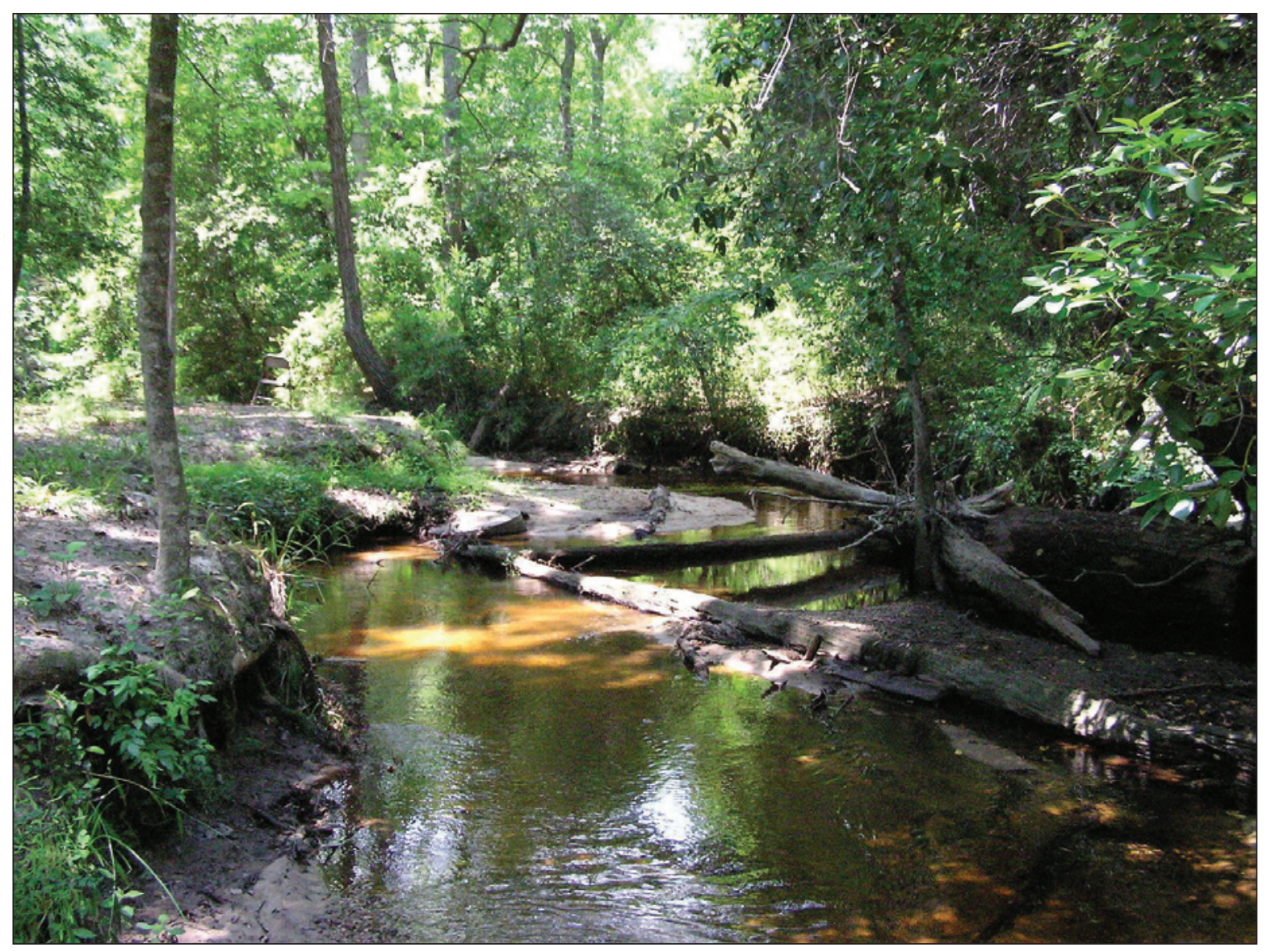

Figure 11. McTier Creek near Monetta, South Carolina (Site 30 in table 1 and figure 10) (summer). Photograph by Paul M. Bradley, U.S. Geological Survey. 


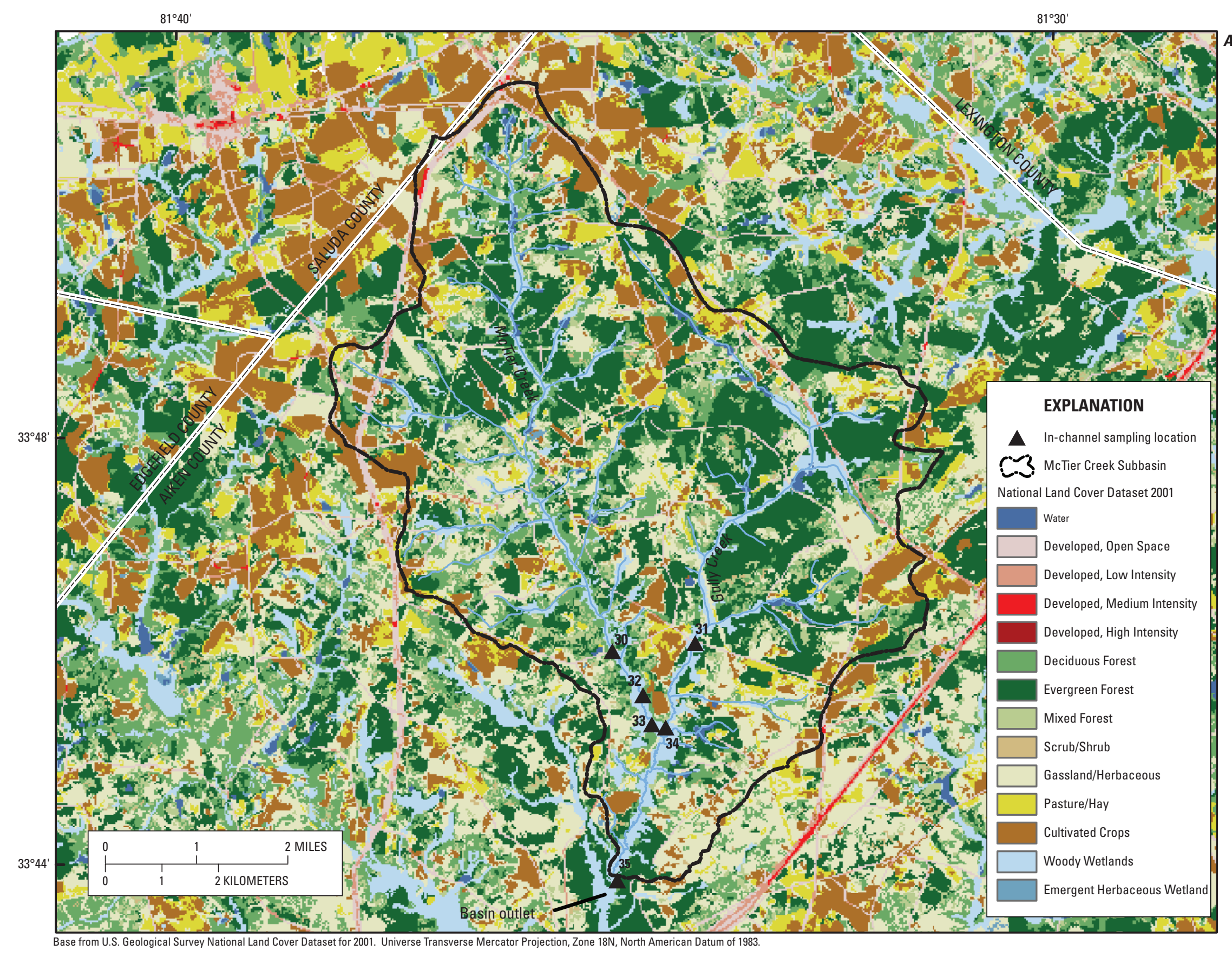

Figure 12A. Detailed land use/land cover and wetland cover for McTier Creek Subbasin: land use/land cover, based on National Land Cover Dataset for 2001. Map numbers refer to sites listed in table 1. 


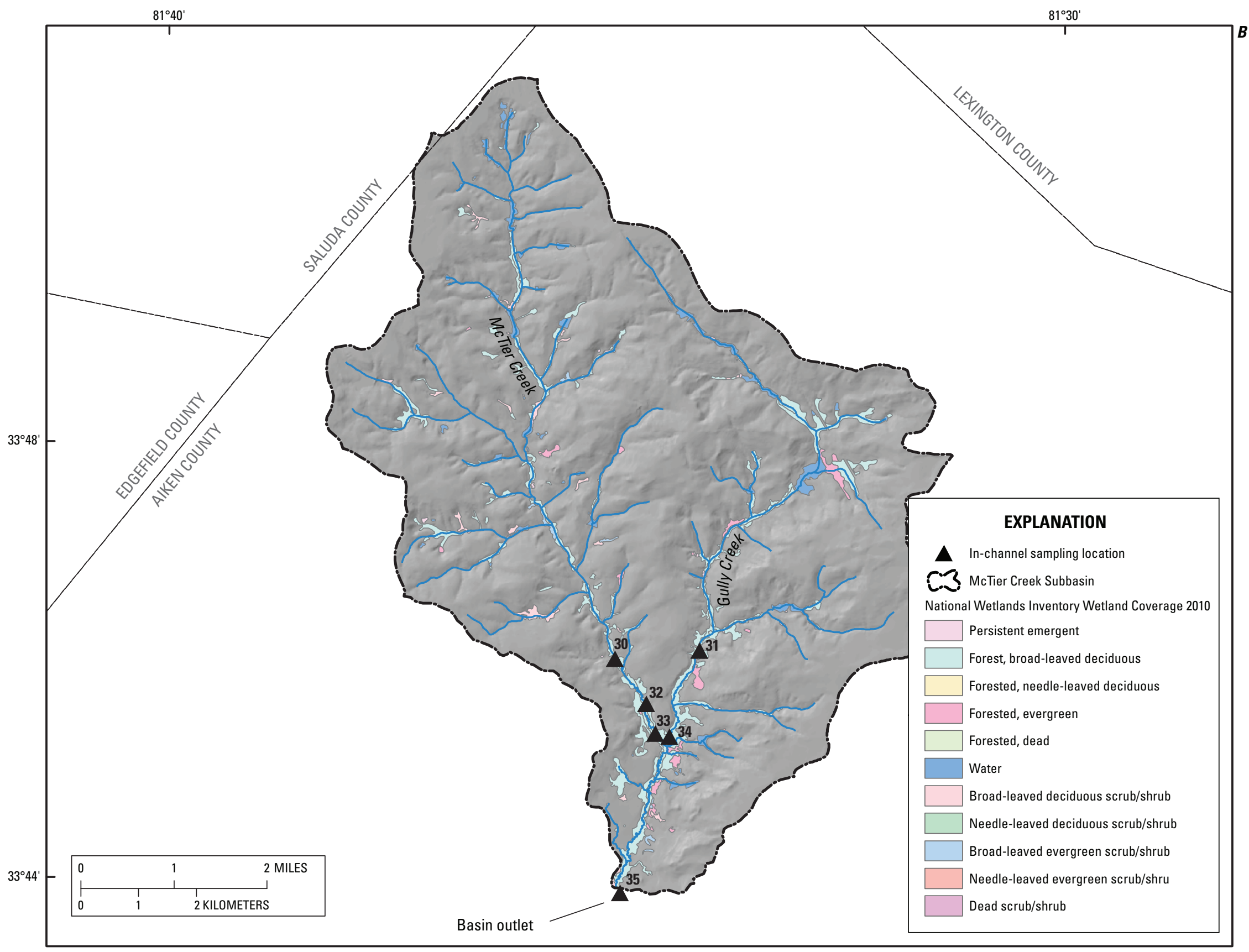

Figure 12B. Detailed land use/land cover and wetland cover for McTier Creek Subbasin: wetland cover, based on U.S. Fish and Wildlife Service National Wetlands Inventory. Map numbers refer to sites listed in table 1. 


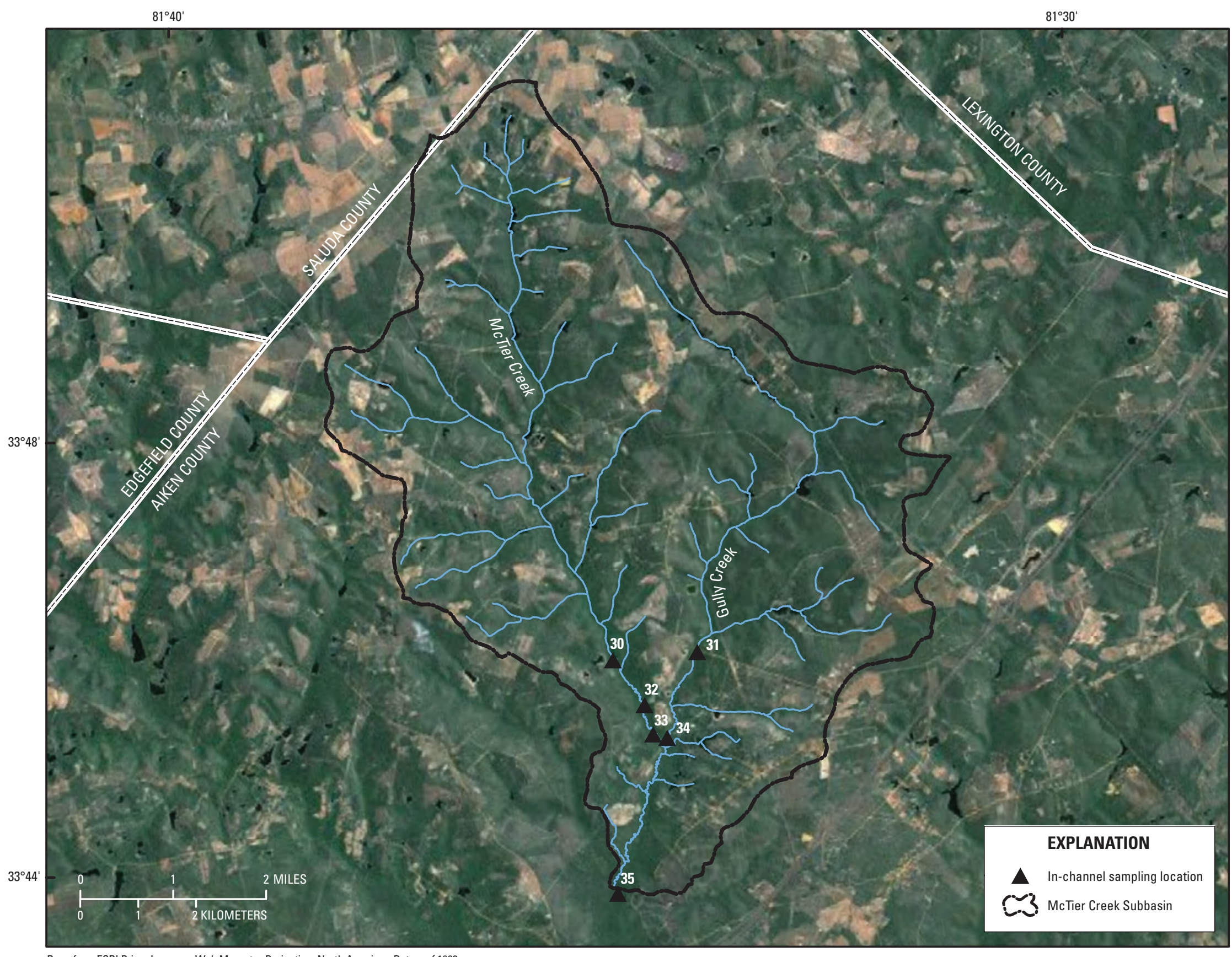

Figure 13. McTier Creek Subbasin, South Carolina, showing sampling locations. Map numbers refer to sites listed in table 1. 
During the study period for the primary sampling site at McTier Creek near New Holland (Site 35), the mean winter-air temperature was $9.1{ }^{\circ} \mathrm{C}$ and the mean summer-air temperature was $26.8^{\circ} \mathrm{C}$. Mean annual precipitation during 2005-2009 averaged $1,134 \mathrm{~mm} / \mathrm{yr}$, with no snow (table 4 ); however, as mentioned earlier, 2007 was an historic drought year for the area.

For estimating atmospheric Hg deposition, NADP-MDN site SC19 is in the nearby Congaree National Park and is the closest NADP-MDN site to the McTier Creek Subbasin; the other nearest NADP site is NTN site SC06, which monitors concentrations of acids, base cations, and nutrients but not $\mathrm{Hg}$, and is in the Santee National Wildlife Refuge (tables 2 and 4). Mean total Hg, precipitation-weighted, in wet atmospheric deposition was $10.2 \mu \mathrm{g} / \mathrm{m}^{2} / \mathrm{yr}$, which is larger than the value of $6.69 \mu \mathrm{g} / \mathrm{m}^{2} / \mathrm{yr}$ for Fishing Brook in New York. This does not consider dry atmospheric deposition, which can be significant in both study areas (Miller and others, 2005; Sakata and others, 2006; Choi and others, 2008; Risch and others, 2011).
In contrast with the free-flowing Edisto River, there are at least a dozen small (less than 2 ha), man-made impoundments along McTier Creek upstream of the Monetta site. Mean annual streamflow was $16.4 \mathrm{ft}^{3} / \mathrm{s}$ (WYs 2007-09) for McTier Creek near New Holland (table 6). McTier Creek near New Holland, S.C. (Site 35), had mean annual streamflows of $19.2 \mathrm{ft}^{3} / \mathrm{s}$ in WY 2008 and $26.4 \mathrm{ft}^{3} / \mathrm{s}$ in WY 2009. As with Fishing Brook, only partial streamflow record existed for 2007 , so no annual statistics were computed for that year. During 2007-09, daily mean water temperatures ranged from 3.0 to $25.7^{\circ} \mathrm{C}$, with a mean annual water temperature of $17.5^{\circ} \mathrm{C}$ (table 7). Mean annual water temperature and range were similar at McTier Creek near Monetta, S.C. (Site 30, table 7).

The major tributary to McTier Creek is Gully Creek, which has shallow ponds from beaver activity (fig. 14). Gully Creek drains a basin of about $30 \mathrm{~km}^{2}$ and joins McTier Creek about $2 \mathrm{~km}$ downstream of the Monetta site.

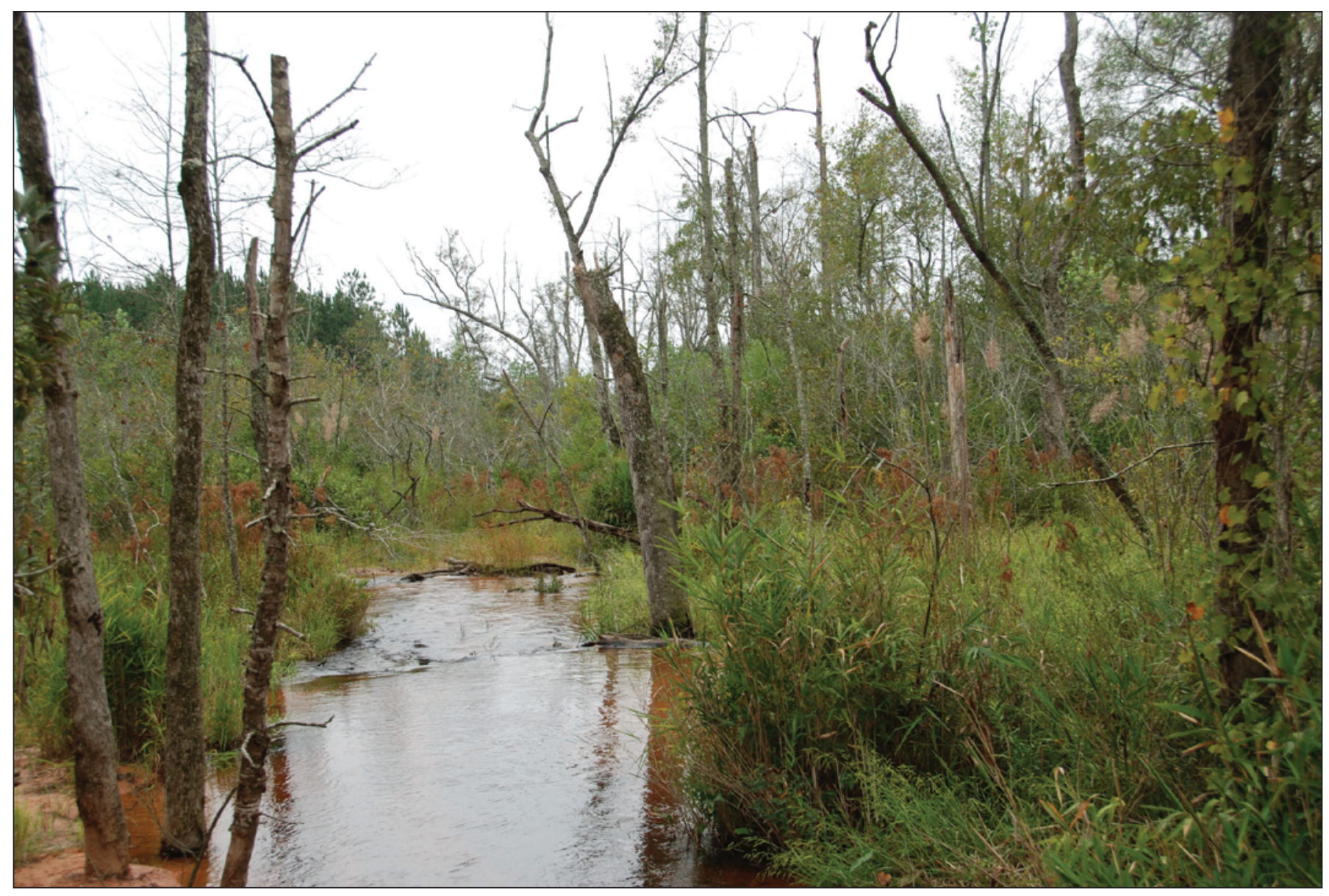

Figure 14. Gully Creek at Bridge on Shoals Road near Monetta, South Carolina, major tributary to McTier Creek (Site 31) (fall). Photograph by Celeste A. Journey, U.S. Geological Survey. 


\section{Summary}

Mercury $(\mathrm{Hg})$ bioaccumulation in streams draining contrasting environmental settings across the United States is the focus of studies by the U.S. Geological Survey (USGS). This report describes environmental settings of stream sites that were investigated with regard to $\mathrm{Hg}$ cycling and bioaccumulation: Upper Hudson River Basin in New York and its headwater subbasin, Fishing Brook; and Edisto River Basin in South Carolina and its headwater subbasin, McTier Creek. Atmospheric deposition is the dominant $\mathrm{Hg}$ source. Biota, sediment, and water were sampled for $\mathrm{Hg}$ and additional physical and chemical characteristics thought to be important to $\mathrm{Hg}$ cycling and bioaccumulation. The primary sampling areas were Fishing Brook and McTier Creek Subbasins. The Fishing Brook sites are in the mountainous Adirondack region of New York where the climate is temperate continental, and the McTier Creek sites are in the lowland Coastal Plain region of South Carolina where the climate is sub-tropical. Land use/ land cover in both is mostly rural, with higher percentages of forested upland in Fishing Brook Subbasin when compared to McTier Creek Subbasin. The percentage of wetland in Fishing Brook Subbasin was fairly similar to that of McTier Creek Subbasin; most wetland in both basins was wooded wetland. An important difference in the environmental settings of the two basins is the heterogeneity of Fishing Brook Subbasin in terms of landscape characteristics, such as slope and amounts of wetland and open water, in contrast to the much more homogeneous landscape characteristics of McTier Creek Subbasin. The USGS studies are designed to evaluate environmental characteristics that affect $\mathrm{Hg}$ bioaccumulation in these two $\mathrm{Hg}$-sensitive ecosystems.

\section{References Cited}

Bauch, N.J., Chasar, L.C., Scudder, B.C., Moran, P.W., Hitt, K.J., Brigham, M.E., Lutz, M.A., and Wentz, D.A., 2009, Data on mercury in water, bed sediment, and fish from streams across the United States, 1998-2005: U.S. Geological Survey Data Series 307, 33 p.

Bell, A.H., and Lutz, M.A., 2008, Environmental settings of selected streams sampled for mercury in Oregon, Wisconsin, and Florida, 2002-06: U.S. Geological Survey OpenFile Report 2008-1277, 34 p.

Bradley, P.M., Burns, D.A., Riva-Murray, Karen, Brigham, M.E., Button, D.T., Chasar, L.C., Marvin-DiPasquale, Mark, Lowery, M.A., and Journey, C.A., 2011, Spatial and seasonal variability of dissolved methylmercury in two stream basins in the eastern United States: Environmental Science and Technology, v. 45, p. 2048-2055.

Bradley, P.M., Chapelle, F.H., and Journey, C.A., 2009, Comparison of methylmercury production and accumulation in sediments of the Congaree and Edisto River Basins, South Carolina, 2004-06: U.S. Geological Survey Scientific Investigations Report 2009-5021, 9 p.

Bradley, P.M., Journey, C.A., Chapelle, F.H., Lowery, M.A., and Conrads, P.A., 2010, Flood hydrology and methylmercury availability in Coastal Plain rivers: Environmental Science and Technology, v. 44, p. 9285-9290.

Brigham, M.E., Krabbenhoft, D.P., and Hamilton, P.A., 2003, Mercury in stream ecosystems-New studies initiated by the U.S. Geological Survey: U.S. Geological Survey Fact Sheet 016-03, 4 p.

Brigham, M.E., Wentz, D.A., Aiken, G.R., and Krabbenhoft, D.P., 2009, Mercury cycling in stream ecosystems-1. Water column chemistry and transport: Environmental Science and Technology, v. 43, no. 8, p. 2720-2725.

Chasar, L.C., Scudder, B.C., Stewart, A.R., Bell, A.H., and Aiken, G.R., 2009, Mercury cycling in stream ecosystems-3. Trophic dynamics and methylmercury bioaccumulation: Environmental Science and Technology, v. 43, no. 8, p. 2733-2739.

Chumchal, M.M., Drenner, R.W., Fry, Brian, Hambright, K.D., and Newland, L.W., 2008, Habitat-specific differences in mercury concentrations in a top predator from a shallow lake: Transactions of the American Fisheries Society, v. 137, p. 195-208.

Choi, Hyun-Deok, Sharac, T.J., Holsen, T.M., 2008, Mercury deposition in the Adirondacks: A comparison between precipitation and throughfall: Atmospheric Environment, v. 42, p. $1818-1827$. 
Daly, Christopher, 2006, Guidelines for assessing the suitability of spatial climate data sets: International Journal of Climatology, v. 26, no. 6, p. 707-721.

Daly, Christopher, Gibson, W.P., Taylor, G.H., Johnson, G.L., and Pasteris, Phillip, 2002, A knowledge-based approach to the statistical mapping of climate: Climate Research, v. 22, p. $99-113$.

Daly, Christopher, Neilson, R.P., and Phillips, D.L., 1994, A statistical-topographic model for mapping climatological precipitation over mountainous terrain: Journal of Applied Meteorology, v. 33, p. 140-158, accessed September 7, 2011, at http://prism.oregonstate.edu/pub/prism/docs/ jappclim94-modeling_mountain_precip-daly.pdf.

Driscoll, C.T., Yan, Cheng, Schofield, C.L., Munson, Ron, and Holsapple, John, 1994, The mercury cycle and fish in the Adirondack lakes: Environmental Science and Technology, v. 28 , no. 3 , p. $136-143$.

Environmental Systems Research Institute, 2007, Prime Imagery Data for McTier Creek, courtesy of AEX Aerials Maps and Data, 0.5 meter resolution, accessed March 2007, at http://www.aerials-gis.com/AEX_Site/GIS_System.html.

Environmental Systems Research Institute, 2008, Prime Imagery Data for Fishing Brook, courtesy of U.S. Department of Agriculture-Farm Service Agency, National Agriculture Imagery Program, 1.0 meter resolution, accessed October 2008, at $h t t p: / / w w w . a r c g i s . c o m / h o m e / i t e m . h t m l ? i d=5 f 5 f 6 b 9$ ee5b4483f9767b118b7b99323.

Evers, D.C., Young-Ji, Han, Driscoll, C.T., Kamman, N.C., Goodale, M.W., Lambert, K.F., Holsen, T.M., Chen, C.Y., Clair, T.A., and Butler, Thomas, 2007, Biological mercury hotspots in the northeastern United States and southeastern Canada: BioScience, v. 57, no.1, p. 29-43.

Feaster, T.D., Golden, H.E., Odom, K.R., Lowery, M.A., Conrads, P.A., and Bradley, P.M., 2010, Simulation of streamflow in the McTier Creek watershed, South Carolina: U.S. Geological Survey Scientific Investigations Report 2010-5202, $61 \mathrm{p}$.

Glover, J.B., Domino, M.E., Altman, K.C., Dillman, J.W., Castleberry, W.S., Eidson, J.P., and Mattocks, Micheal, 2010, Mercury in South Carolina fishes, USA: Ecotoxicology, v. 19, no. 4, p. 781-795.

Griffith, G.E., Omernik, J.M., Comstock, J.A., Schafale, M.P., McNab, W.H., Lenat, D.R., MacPherson, T.F., Glover, J.B., and Shelburne, V.B., 2002, Ecoregions of North Carolina and South Carolina, (color poster with map, descriptive text, summary tables, and photographs): Reston, Va., U.S. Geological Survey (map scale 1:1,500,000).
Homer, Collin; Huang, Chengquan; Yang, Limin; Wylie, Bruce; and Coan, Michael, 2004, Development of a 2001 national land cover database for the United States: Photogrammetric Engineering and Remote Sensing, v. 70, no. 7, p. 829-840.

Hurley, J.P., Benoit, J.M., Babiarz, C.L., Shafer, M.M., Andren, A.W., Sullivan, J.R., Hammond, Richard, and Webb, D.A., 1995, Influences of watershed characteristics on mercury levels in Wisconsin Rivers: Environmental Science and Technology, v. 29, no. 7, p. 1867-1875.

Jenkins, J., 2004, The Adirondack Atlas-A geographic portrait of the Adirondack Park: Syracuse, N.Y., Syracuse University Press, 275 p.

Kolka, R.K., Nater, E.A., Grigal, D.F., and Verry, E.S., 1999, Atmospheric inputs of mercury and organic carbon into a forested upland/bog watershed: Water, Air, and Soil Pollution, v. 113, p. 273-294.

Krabbenhoft, D.P., Wiener, J.G., Brumbaugh, W.G., Olson, M.L., DeWild, J.F., and Sabin, T.J., 1999, A national pilot study of mercury contamination of aquatic ecosystems along multiple gradients, in U.S. Geological Survey Toxic Substances Hydrology Program-Proceedings of the Technical Meeting, Charleston, S.C., March 8-12, 1999, Volume 2 of 3 - Contamination of hydrologic systems and related ecosystems: U.S. Geological Survey Water-Resources Investigations Report 99-4018-B, p. 147-160.

Latysh, N.E., and Wetherbee, G.A., 2007, External quality assurance programs managed by the U.S. Geological Survey in support of the National Atmospheric Deposition Program/Mercury Deposition Network: U.S. Geological Survey Open-File Report 2007-1170, 33 p.

Latysh, N.E., and Wetherbee, G.A., 2011, Improved mapping of National Atmospheric Deposition Program wet-deposition in complex terrain using PRISM-gridded data sets: Environmental Monitoring and Assessment, DOI 10.1007/

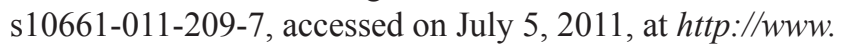
springerlink.com/content/bg0vg56668j360j6/fulltext.pdf.

Marvin-DiPasquale, Mark, Lutz, M.A., Brigham, M.E., Krabbenhoft, D.P., Aiken, G.R., Orem, W.H., and Hall, B.D., 2009, Mercury cycling in stream ecosystems - 2. Benthic methylmercury production and bed sediment-Pore water partitioning: Environmental Science and Technology, v. 43, no. 8, p. 2726-2732.

Miller, E.K., Vanarsdale, Alan, Keeler, G.J., Chalmers, Ann, Poissant, Laurier, Kamman, N.C., and Brulotte, Raynald, 2005, Estimation and Mapping of Wet and Dry Mercury Deposition Across Northeastern North America: Ecotoxicology, v. 14, p. 53-70. 
National Atmospheric Deposition Program, 2006, Mercury Deposition Network Quality Assurance Plan-Mercury Analytical Laboratory, 2006, accessed on August 23, 2011, at http://nadp.sws.uiuc.edu/lib/qaplans/qapHAL2006.pdf.

National Atmospheric Deposition Program, 2010a, Mercury Deposition Network sites, accessed October 14, 2010, at http://nadp.sws.uiuc.edu/sites/mdnmap.asp.

National Atmospheric Deposition Program, 2010b, Mercury Deposition Network data, accessed October 14, 2010, at http://nadp.sws.uiuc.edu/mdn.

National Climatic Data Center, 2011a, Local climatological data publication: National Oceanic and Atmospheric Administration, National Environmental Satellite, Data, and Information Service, accessed March 30, 2011, at http://www.ncdc.noaa.gov/oa/climate/stationlocator.html.

National Climatic Data Center, 2011b, Freeze/frost mapsFreeze free period, $90 \%$ probability of a longer duration (days) with temperatures above $32^{\circ} \mathrm{F}$ : National Oceanic and Atmospheric Administration, accessed August 19, 2011, at http://www.ncdc.noaa.gov/img/climate/freezefrost/ Freezefree32F.pdf.

National Oceanic and Atmospheric Administration and South Carolina Department of Natural Resources, 2011, Characterization of the Ashepoo-Combahee-Edisto (ACE) Basin, South Carolina: on CD-ROM, accessed July 8, 2011, at http://www.dnr.sc.gov/marine/mrri/acechar/esmodel.htm.

National Water and Climate Center, 2010, Parameter-elevation Regressions on Independent Slopes Model (PRISM): Natural Resources Conservation Service, accessed on July 5, 2011, at http://www.wcc.nrcs.usda.gov/climate/prism.html.

Natural Resources Conservation Service, 2010, Watershed Boundary Dataset, accessed July 2010, at $h t t p: / / w w w . n c g c$. nrcs.usda.gov/products/datasets/watershed/.

Natural Resources Conservation Service, 2011, Soil survey geographic (SSURGO) database, accessed February 16, 2011, at http://soils.usda.gov/survey/geography/ssurgo/.

New York State Adirondack Park Agency, 2007, Wetlands in the Greater Upper Hudson River Watershed, accessed February 2007, at http://www.apa.state.ny.us/gis/index.html.

New York State Adirondack Park Agency, 2011, Town of Newcomb, Essex County, Historic Tahawus Tract, accessed September 7, 2011, at http://www.apa.state.ny.us/Press/ OSI_Tahawus.htm.

New York State Department of Environmental Conservation, 2008, Strategic monitoring of mercury in New York State fish: Report 08-11 to New York State Energy Research and Development Authority [variously paged].
New York State Department of Health, 2011, Chemicals in sportfish and game-2010-2011 Health advisories, 36 p., accessed August 2011, at www.health.ny.gov/environmental/ outdoors/fish/fish.htm.

Omernik, J.M., 1987, Ecoregions of the conterminous United States, map (scale 1:7,500,000): Annals of the Association of American Geographers, v. 77, no. 1, p. 118-125.

Pack, A.B., 1960 (revised 1972), Climate of New York, in the series "Climate of the States - Climatography of the United States: Silver Spring, Md., National Oceanic and Atmospheric Administration, Environmental Data Service Report 60-30, accessed December 29, 2010 at http://nysc. eas.cornell.edu/climate_of_ny.html.

PRISM Climate Group, 2010, Oregon State University, http://prism.oregonstate.edu.

Risch, M.R., DeWild, J.F., Krabbenhoft, D.P., Kolka, R.K., Zhang, Leiming, 2012, Litterfall mercury dry deposition in the eastern USA: Environmental Pollution, vol. 161, pp. 284-290.

Riva-Murray, Karen, Chasar, L.C., Bradley, P.M., Burns, D.A., Brigham, M.E., Smith, M.J., and Abrahamsen, T.A., 2011, Spatial patterns of mercury in macroinvertebrates and fishes from streams of two contrasting forested landscapes in the eastern United States: Ecotoxicology, v. 20, no. 7, p. $1530-1542$.

Sakata, Masahiro; Marumoto, Kohji; Narukawa, Masahiro; and Asakura, Kazuo, 2006, Regional variations in wet and dry deposition fluxes of trace elements in Japan: Atmospheric Environment, v. 40, no. 3, p. 521-531.

Scudder, B.C., Chasar, L.C., Wentz, D.A., Bauch, N.J., Brigham, M.E., Moran, P.W., and Krabbenhoft, D.P., 2009, Mercury in fish, bed sediment, and water from streams across the United States, 1998-2005: U.S. Geological Survey Scientific Investigations Report 2009-5109, 74 p.

Simonin, H.A., Loukmas, J.J., Skinner, L.C., Roy, K.M., and Paul, E.A., 2009, Trends in mercury concentrations in New York State fish: Bulletin of Environmental Contamination and Toxicology, v. 83, p. 214-218.

South Carolina Department of Health and Environmental Control, 2010, South Carolina mercury assessment and reduction initiative: Columbia, S.C., 98 p.

South Carolina Department of Health and Environmental Control, 2011, South Carolina-Fish consumption advisories: Publication ML-004042, 36 p., accessed September 9, 2011, at http://www.scdhec.gov/administration/library/ ML-004042.pdf. 
South Carolina State Climatology Office, 2011, South Carolina Climate: South Carolina Department of Natural Resources-South Carolina State Climatology Office, accessed November 14, 2011 at $h t t p: / / w w w . d n r . s c . g o v /$ climate/sco/ClimateData/cli_sc_climate.php.

St. Louis, V.L., Rudd, J.W.M., Kelly, C.A., Beaty, K.G., Bloom, N.S., and Flett, R.J., 1994, Importance of wetlands as sources of methyl mercury to boreal forest ecosystems: Canadian Journal of Fisheries and Aquatic Sciences, v. 51, no. 5, p. 1065-1076.

St. Louis, V.L., Rudd, J.W.M., Kelly, C.A., Beaty, K.G., Flett, R.J., and Roulet, N.T., 1996, Production and loss of methylmercury and loss of total mercury from boreal forest catchments containing different types of wetlands: Environmental Science \& Technology, v. 30, no. 9, p. 2719-2729.

State University of New York-College of Environmental Science and Forestry, 2011, Adirondack forest communities: Syracuse, N.Y., Adirondack Ecological Center/Huntington Wildlife Forest, accessed May 17, 2011, at http://www.esf. edu/aec/adks/forestcomm.htm.

System for Automated Geoscientific Analysis Geographic Information System (SAGA), 2007, System for automated geoscientific analysis, version 2.0: Department of Physical Geography, Gottingen, accessed September 9, 2011, at http://www.saga-gis.org/en/index.html.

U.S. Environmental Protection Agency, 1997, Mercury study report to Congress, Vol. 3-Fate and transport of mercury in the environment: Washington, D.C., Office of Air Quality Planning and Standards and Office of Research and Development, EPA-452/R-97-005, 376 p.

U.S. Environmental Protection Agency, 2001a, Total mercury daily limit (TMDL) for total mercury in fish tissue residue in the middle and lower Savannah River watershed: U.S. Environmental Protection Agency-Region 4, accessed February 2006 at http://www.epa.gov/Region4/water/tmdl/ georgia/final/savannah_hg_final.pdf.

U.S. Environmental Protection Agency, 2001b, Water quality criterion for protection of human health-Methylmercury: Washington, D.C., Technical Report EPA/823/R-01/001 [variously paged].

U.S. Environmental Protection Agency, 2005, Omernik's level III ecoregions of the continental United States: Reston, Va., National Atlas of the United States, scale 1:7,500,000, accessed September 9, 2011, at http://nationalatlas.gov/mld/ ecoomrp.html.

U.S. Fish and Wildlife Service, 2010, National Wetlands Inventory, accessed July 2010, at http://www.fws.gov/ wetlands/.
U.S. Geological Survey, 2010a, National Elevation DatasetDigital Elevation Model, accessed July 2010, at http://ned. usgs.gov/.

U.S. Geological Survey, 2010b, National Hydrography Dataset, accessed July 2010, at http://nhd.usgs.gov/.

U.S. Geological Survey, 2010c, National Water Information System, accessed December 2010, at http://waterdata.usgs. gov/nwis/measurements.

Yang, Limin, Huang, Chengquan, Homer, C.G., Wylie, B.K., and Coan, M.J., 2002, An approach for mapping large-area impervious surfaces-Synergistic use of Landsat 7 ETM+ and high spatial resolution imagery: Canadian Journal of Remote Sensing, v. 29, no. 2, p. 230-240.

Yeardley, R.B., Jr., Lazorchak, J.M., and Paulsen, S.G., 1998, Elemental fish tissue contamination in northeastern U.S. lakes-Evaluation of an approach to regional assessment: Environmental Toxicology and Chemistry, v. 17, no. 9, p. $1875-1884$. 


\section{Appendix 1. Detailed Geographic Information System data for selected streams sampled in New York for U.S. Geological Survey mercury studies, 2005-09.}

Appendix1.xlsx (Excel 68KB) is available on the HTML page in Excel format.

\section{Appendix 2. Detailed Geographic Information System Data for Selected Streams Sampled in South Carolina for U.S. Geological Survey Mercury Studies, 2005-09.}


Publishing support provided by the:

Columbus Science Publishing Network

For more information concerning this publication, contact: Director, Wisconsin Water Science Center

U.S. Geological Survey

8505 Research Way

Middleton, WI 53562

(608) 828-9901

Or visit the Wisconsin Water Science Center Web site at: http://wi.water.usgs.gov/ 



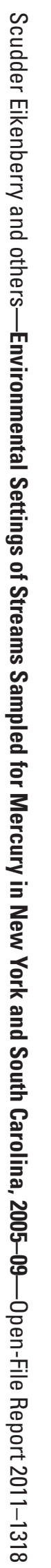

